\title{
Freedom of Worship as warranted in Islam - in light of Manuscripts and Documents (Historical and Archaeological Study)
}

\section{Dr.Boussy M. Zidan}

\section{Abstract:}

Recently, extremists entitled "ISIS" have been committing unusual behaviors, including persecution, severe punishment, killing, slanting, and burning people alive in the name of Islam. These aggressions are committed against non-Muslims, e.g. Christians and Yazidis, for no reason but believing in other creeds. Furthermore, they act as the exponent of Sunnah, persecuting Muslims of different sects as well. Thus, an inquiry emerges as follows: is the term "Human Rights" in general, and freedom of worship in particular, as principles, confined to mankind of Western origin, or is it rooted in Islam as a first handler? Proceeding on this paper; it is become clear that "Human Rights" is not an outcome of western civilization, but it is deeply rooted from the Holy faiths and particularly among the fundamentals of the Islamic Faith about twelve centuries earlier than the West addressed the issue. Returning to true Islamic faith; Holy Qur'ān and the Prophetic Sunnah are full of several evidences which reject any illegal persecution to Muslims/nonMuslims alike. On the contrary, there are clear evidences ensuring Islamic faith's tolerance and forgiveness with dissidents and the disbelievers. Typically, freedom of worship is a fundamental right for mankind in Islam.

\section{This research aims at:}

-Ensuring that Islam reflects the origin of "Human Rights", especially the freedom of worship.

- Highlighting Islam's innocence of aggressive behaviors of the extremists

\footnotetext{
- Associate professor of Islamic History and Archaeology - Faculty of Tourism and Hotels - Suez Canal University dr.boussyzidan@tourism.suez.edu.eg
} 
- Spreading the concepts of orthodox "true" Islamic faith.

- Facilitating the erection of truth bridges between Islam and the West.

keywords: Extremists, Human rights, Freedom of worship, ISIS, ISIL, Islamic Faith, Prophetic traditions.

\section{Research's plan}

\section{Introduction}

II.Evidences from Qur'ān and Prophetic Sunnah on Freedom of worship

III. Recent behaviors against "Human Rights" in the name of Islam

IV. Manuscripts and archaeological documents referring to freedom of worship in Islam

V.Conclusion

VI. References

VII. Plates

\section{Introduction}

1.1. The term of "Human Rights", and its introduction.

1.2. Is the term of western origin or is it rooted in Islam?

A right is an order, a privilege, power, or immunity which persons own in face of the state. So became limitations on. Thus, the one has to claim them leaning on ethical, and cultural basis accepted by the society. ${ }^{(1)}$ While freedom means the ability to act or choose with free well, and away from any slavery or blaming. ${ }^{(2)}$ In shari'ah; freedom is what distinguishes a human to act, and talk freely with no force, but according to defined rules. ${ }^{(3)}$ Here is an inquiry; is there a difference between right and freedom? Right is accompanied by privacy whereas freedoms are general. ${ }^{(4)}$ Another point of view considers right as basis

\footnotetext{
${ }^{(1)} Y$ ūsūf 'Awād and Others, Huqūq al-Insān fĩ al-Hayāh at-Tarbāwīyya, p. 144

(2) Jūbrān Massoūd, Ar-Rā'id Mū 'jam Laghawy, p.563

${ }^{(3)}$ Ūmar Farhāty, Āliyāt al-Himāya al-Dawlīyya lī-Huqūq Al-Insān, p. 32

${ }^{(4)}$ Ūmar Al-Ḥadīthī, Tajrīm al-Ta'āsūf fì Ist'māl al-Ḥaq, p. 29, 30
} 
before freedom which is defined to be one's ability to manage one's affairs by oneself on one's own without others' interference regardless whether it has been done according to individual or public standard. ${ }^{(5)}$

\section{Terms of "Human Rights"}

Numerous terms are used to refer to "Human Rights". Of these, humanity rights, natural rights, ...etc. are used. Since the $19^{\text {th }}$ century A.D onwards, the term "Human Rights" has predominated. ${ }^{(6)}$ Meaning of "Human Rights" differ from one society to another, and both the meaning and nature of these rights are mainly linked to the concept of humankind. ${ }^{(7)}$ After the world war II (1939-45), actual practice to "Human Rights" had been inaugurated even before the term itself predominated. These practices were connected with the old democratic regimes in line with the Holy faiths and all positive laws. ${ }^{(8)}$

According to personal visions and field of specification, researchers have defined "Human Rights" in several ways. Thus, "Human Rights" is explained as a bundle of rights considerably connected with human personality. These rights are stipulated in the international charters that humans have the benefit of them, regardless of their faith, language, color, origin, descent, sex, etc. ${ }^{(9)}$ Furthermore, "Human Rights" is defined as "all the rights which individuals and groups actually have, passing over regimes' official observance to the international treaties concerned with "Human Rights". ${ }^{(10)}$ Due to multiple definitions of "Human Rights"; it is difficult to set a distinctive one. It is continuously in progress according to international, regional, and local circumstances on political and law standard. There is an unanimous agreement that "Human Rights" are all the rights that

\footnotetext{
${ }^{(5)}$ Muhammad Muhammad, al-Ḥuqūq al-Siyāsīyah li al-Aqalīyyāt, p. 341

${ }^{(6)}$ Claudio Zanghi, al-Ḥ̄̄māyyah al-Dawlīyya lī Huqūq al-Insān, p.3

${ }^{(7)}$ Markaz derāsāt al-Wīḥda al-'Arabiyya, Huqūq al-Insān al-'Arabi, p.95

${ }^{(8)}$ Qadrīi 'Abd al-Majīi, Al-I'lām wā Huquāq al-Insān, p. 23

${ }^{(9)}$ Ad-Dalil al-'Arabi hawl Huqūq al-Insān wa al-Tanmiyyah, p.43

${ }^{(10)}$ Todd Landman, "Measuring Human Rights: principle, Practice and policy", p. 916
} 
ensure a good life in civilian, political, economic, cultural, and social aspects. $^{(11)}$

Hence, as follows, there appear to be a gradual progress in the "Human Rights" issue based on international/regional, local, and religious sources. ${ }^{(12)}$

\section{International sources}

International sources include the worldwide ones for "Human Rights", all the regional charters, treaties that concerned with the issue including;

Worldwide sources

These charters are originated and applied universally. ${ }^{(13)}$ Of these, there is

\section{- The United Nations charter:}

This is the cornerstone in the law concerned with "Human Rights" in contemporary international community. ${ }^{(14)}$ It is the first international charter of a worldwide or semi worldwide features encompassing "Human Rights". (15) It was issued in Francisco in the U.S in June $1945,{ }^{(16)}$ and brought into effect in the $14^{\text {th }}$ of Oct. 1945. ${ }^{(17)}$ Although this charter did not include a definition to "Human Rights"; it greatly cared about it. This appeared clearly from charter's opening statement, as follows: "We are the people of the United Nations, we vowed ourselves to save the coming generations from wars afflictions, which had caused extreme sorrow and sadness for two times through one generation, and to emphasis our belief in the main rights of mankind, his dignity, and honor with no distinction according to sex, and all nations have the same rights". ${ }^{18)}$ However, this charter did not include the basis for "Human Rights" as a result

\footnotetext{
${ }^{(11)}$ Nesrīn Muhammad 'Abdū Hassūna, Huqūq al-Insān, p. 10

${ }^{(12)}$ Aḥmad ar-Rashīdī, 'Adnān Hūsseīn, Ḥuqūq al-Insān, p. 36

${ }^{(13)}$ Al-Shafi'i Muhammad Bashīr, Qānūn Huqūq al-Insān, p. 49

${ }^{(14)}$ Ibrāhīm Ma'amr, Dūr al-Mūnazamāt ad-Dawlīyyah al-Ghīr hūkūmīyyah, p.9

${ }^{(15)}$ Hassānīn Bawādi, Huqūq al-Insān, p. 15

${ }^{(16)}{ }^{17}{ }^{2} \overline{1}$ Ta'īmāt, Huqūq al-Insān wa Hūūiyyātūh, p. 67

${ }^{(17)}$ Mahmūd Qandil, al-Ūmam al-Mūtahīidah wa himāyt Huqūq al-Insān, p. 10

${ }^{(18)}$ Jābir ar-Rāwī, Ḥuqūq al-Insān wa Ḥūriyyātūh, p. 54, 55.
} 
of coming after the World War II. Hence, the main purpose was to avoid any other wars.

\section{- The international charter for "Human Rights"}

On the $17^{\text {th }}$ of December 1947, the committee of "Human Rights" on its $12^{\text {th }}$ convention in Geneva generalized this term on a group of deeds. Among these deeds were included in the international charter for "Human Rights", the international treaty for economic, social, and cultural rights, and the international treaty for civilian and political rights. ${ }^{(20)}$ These together are identified as the international charter for "Human Rights". This considered the base from which various international law documents of the UN had originated. In addition; it enclosed principles and general rules mainly linked to "Human Rights", which were considered obligatory for the countries to be committed to. (22)

Documents of the international charter

- The first document is the worldwide treaty for "Human Rights".

On the $10^{\text {th }}$ of December, 1948A.D, the general assembly of the United States defined the principles of the worldwide charter for "Human Rights". ${ }^{(23)}$ It is considered the first and main international report dealing with the rights of all mankind. ${ }^{(24)}$ This charter is a standard put into action by all nations to evaluate their success in honoring "Human Rights". ${ }^{(25)}$ However; it is not obligatory to the member countries in the United Nations; but it is a moral value with no guarantees to prevent its infraction. ${ }^{(26)}$ This charter is one of the United Nations' most famous and effective documents within the international

\footnotetext{
${ }^{(19)}$ Sūhail al-Fatlāwī, Huqūq al-Insān, p. 55

${ }^{(20)}$ Muhammad 'Elwān, Muhammad al-Mūsā, al-Qānūn Al-Dawli lī hūqūq al-Insān, p. 88

${ }^{(21)}$ Aḥmad Abū Al-Wafā, al-Ḥ̄māyah ad-Dawlīyyah lī Ḥuqūq al-Insān, p. 27

${ }^{(22)}$ Cecilia M. Bailliet, "Reinterpreting Human Rights through global Media", p. 38

(23) ‘Ūrūpa al-Khazraj̄̄i, al-Qānūn al-Dawlī lī Ḥuqūq al-Insān, p.60

${ }^{(24)}$ Raḍwān Zīyāda, Masīrat Huqūq al-Insān, p. 38- 44

${ }^{(25)}$ Sa'dī Al-Khat̄īb, Huqūq al-Insān wā Damānataha al-Dīstūrīyya, p. 16

${ }^{(26)}$ Qaḍrī al-Atrash, Madkhl ela Qadaya Hūqūq al-Insān, p.66
} 
community. In addition, most of the rights mentioned are listed in the national constitutions and the local legislations in most countries. ${ }^{(27)}$ This charter included economic, social, and cultural rights as well as civilian and political ones. ${ }^{(28)}$

- The second document is the international treaty which was concerned with economic, social, and cultural rights. This international treaty was presented for signature, certification, and association according to the decree no. 2200 of the General Assembly of the United Nations on the $16^{\text {th }}$ of December 1966. The treaty coped with the treaty's item no. 27 on the $3^{\text {rd }}$ of January 1976 A.D. ${ }^{(29)}$ This treaty listed the rights concluded in the charter of the United Nations and seen as more inclusive than the rights listed in the worldwide charter for "Human Rights". ${ }^{(30)}$

- The third document is the international Charter of political and civilian rights.

This charter was accredited and presented to be signed and certified in association to the decree no. 2200 of the General Assembly of the United Nations on the $16^{\text {th }}$ of December 1966 and began to be carried out according to item no. 49 on the $23^{\text {rd }}$ of March1976. ${ }^{(31)}$ This charter searched for international means to protect "Human Rights" which had already been decreed. Thus, it made the treaty more distinguished than the first document (i.e. the Worldwide Charter for "Human Rights"). Furthermore, a special committee for "Human Rights" was constituted under the United Nations control, in order to ensure and supervise the application of these rights. ${ }^{(32)}$

- The international Charter confirmed the following rights: in life, liberty, saving personality reservation, freedom of thoughts,

\footnotetext{
${ }^{(27)}$ Karima al-Tāī, Hūsseīn al-Darderī, Huqūq al-Insān wa Ḥūriyyātūh, p. 47

${ }^{(28)}$ Taïeb Baccouche, "Athr Ḥuqūq al-Insān fĩ Tatwīr al-mafāhīm al-Thaqāfìyyah”, p. 104

${ }^{(29)}$ David Wesburdn and others, mū khtārāt mn Adāwāt Huqūq al-Insān al-Dawliyya, p. 51

(30) 'Essam Zanātī, Hīmayat Huqūq al-Insān, p. 83- 92

${ }^{(31)}$ Nasir al-Sayed, al-Himāyah al-Dawliyya lī-hūrayat I'tīnāq, p. 130

${ }^{(32)}$ Hanī Ta'īmāț, Ḥuqūq al-Insān wa Ḥūriyyātūh al-Assāssīyyah, p. 71
} 
freedom of worship, and equality before law. ${ }^{(33)}$ There are the decrees of the United Nations concerning "Human Rights" as well. Of these the decree no 52/122 of the General Assembly stated the destruction of all shapes of intolerance that had somehow been decreed in $1997 .{ }^{(34)}$

\section{B- Regional sources}

Several regional charters and treaties had been concluded to protect "Human Rights" in Europe, United States, Africa, Arab countries, and Muslim organizations. These charters formed critical sources for "Human Rights" besides the previously mentioned worldwide sources. These charters are follows:

1. The European treaty for "Human Rights" signed in November 1950 brought into effect on the $3^{\text {rd }}$ of September 1953 as approved by the 21 countries members in the European council at that time. ${ }^{(35)}$

2. The American treaty for "Human Rights" which the American Countries Organization had issued for "Human Rights" in San Jose on the $22^{\text {nd }}$ of November 1969. It was brought into effect on the $18^{\text {th }}$ of July $1978 .{ }^{(36)}$

3. The African Charter for "Human Rights" approved by the United African Organization in 1981 and brought into effect on the $21^{\text {st }}$ of October 1986. The existence of the African Committee for "Human Rights" was to ensure its application. ${ }^{(37)}$ However, it is of a weak phrasing in light of commitments of the African States involved. Thus, it is of a lower grade of protection if compared with the European and American systems. (38)

4. The Arabian Charter for "Human Rights" which has been issued and accredited in its premier copy based on decree no 5427 of the League of the Arab States on the $10^{\text {th }}$ of September

\footnotetext{
${ }^{(33)}$ Sa' dī Al-Khatî̄b, Hūqūq al-Insān wā Damānatahah al-Dīstūrīyya, p. 33

${ }^{(34)}$ Aḥmad Abū Al-Wafā, al-Ḥ̄māyah ad-Dawlīyyah lī ḥu qū q al-Insān, p. 36

${ }^{(35)}$ Nasir al-Sayed, al-Himāyah al-Dawliyya lī-hūrayat I'tīnāq, p. 138

${ }^{(36)}$ Karima al-Tāī, Hūsseīn al-Darderī, Huqū̄q al-Insān wa Ḥūriyyātūh al-Assāsssīyyah, p. 78

(37)، Ali Al-Na'ūq, Huqūq al-Insān, p. 3

${ }^{(38)}$ Tārīq Rakhā, Qānūn Hūqūq al-Insān, p. 19
} 
1997 A.D. Its second copy was issued and accredited on the $16^{\text {th }}$ Arabs League in Tunisia on the $23^{\text {rd }}$ of May 2004 A.D. ${ }^{(39)}$ This charter deals with the civilian, political, economic, social, and cultural rights in light of international charter. ${ }^{(40)}$ It is worth mentioning that The Arabian was charter dictated to establish an expert committee of "Human Rights" but it was mostly not specialized in the issue. ${ }^{(41)}$

\section{Local Sources}

These sources include constitutions and local legislations that include items concerned with "Human Rights". ${ }^{(42)}$

\section{Religious Sources}

These sources had drawn up thoughts and practical bases for human right. There is no doubt that respecting equal rights of all mankind without putting in mind any racial discrimination is among the supreme values and ruling principles laid down and included in the three holy faiths (Judaism, Christianity, and Islam). ${ }^{(43)}$

Despite all the previously mentioned international and regional charters; however, "Human Rights" is not the outcome of the Western civilization, but its roots are believed to be among the main contents of the Holy faiths and Islam in particular. ${ }^{(44)}$

Islam is the premiere or the first to state the principles of "Human Rights" in its complete form. ${ }^{(45)}$ It settled the basis of the international law for "Human Rights" and preceded the West in protecting these rights. ${ }^{(46)}$ Islam bestowed right in life and considered honoring this right to be obligatory. ${ }^{(4)}$ Islam had manipulated humankind conditions and put into effect principals

\footnotetext{
${ }^{(39)}$ Hana' Ibrāhīm, 'Ali al-Hadībī, Ta'līm Huqūq al-Insān, p. 37

${ }^{(40)}$ Al-Shafi'i Muhammad Bashīr, Qānūn Huqūù al-Insān, p. 82

${ }^{(41)}$ Tārīq Rakhā, Qānūn Huqūq al-Insān, p. 20, 21

${ }^{(42)}$ Al-Shafi'i Muhammad Bashīr, Qānūn Huqūq al-Insān, p.44

${ }^{(43)}$ Qaḍī 'Abd al-Majīd, Al-I'lām wā Huqūq al-Insān, p. 62

${ }^{(44)}$ Hassānīn Bawādi, Huqūq al-Insān wa Damānāt al-Mūtaham, p. 105

(45)، Attīyya khalīl ‘Attiyya, Asāssiyyāt fĩ Huquāq al-Insān, p. 29

(46)،A Abd el-Kareem Khalifa, al- Qānūn ad-Dawlī lī-Huqūq al-Insān, p. 29

(47)،Ali Muhammad Ad-Dabās, 'Ali 'Eliān Abū Zaied, Ḥuqūq al-Insān wa Ḥū riyātūh, p. 37
} 
of the political, social, and civilian rights. Such interests in rights and benefits for humans were neither reflected or reached in other holy faith nor was fully expressed in any positive legislation all over the world. ${ }^{(48)}$ Islamic faith drew up a complete charter dealing with "Human Rights" and liberties, ${ }^{(49)}$ and established a precise system with warranties sufficient to protect them. This occurred about twelve centuries earlier than the declaration of the rights decreed from the American and French revolutions towards the end of the $18^{\text {th }}$ century, and fourteen centuries earlier than issuing the Worldwide charter of "Human Rights" in 1948 A.D. These rights basically are found in the holy Qur'ān and the prophetic traditions to be, ${ }^{(50)}$ however, later represented as "human being discovery" as an achievement just obtained at the time of the French revolution. The principal rights for mankind are equality and freedom. Modern democratic nations have pretended that the world owes them for issuing those two rights. Gratitude for Britain was expressed as they were assumed to be the deep-rooted people who handled "Human Rights". Furthermore, the French pretended that recognizing and accrediting these rights came as a result of their revolution. Other nations pretended their share in accrediting these rights as well.

However, Islamic faith was the first to issuing the principals of "Human Rights" in its complete image. During Prophet Muhammad's (PBUH) life and the orthodox caliphs' eras, Muslims were the preceding community in following them. The charter of the United Nations about "Human Rights" is just a reappeal for noble commandment that Muslims received from the last of the prophets Muhammad ibn Abdullah (PBUH).

As the last of the holy faiths, Islam, encloses all instructions that preserve a stable life for all human beings. Thus, it encompasses all the rights needed for mankind, and it detailed

\footnotetext{
${ }^{(48)}$ Jābir ar-Rāwī, Ḥuqūq al-Insān wa Ḥūriyyātūh al-Assāssīyyah, p.252

(49) 'Ali Al-Shūkrī, Huqūq al-Insān fi Dhhīl al-‘Awlamah, p. 61

${ }^{(50)}$ Nesrīn Muhammad 'Abdū Hassūna, Hūqūq al-Insān al-Mafhūm wa al-Khașāīṣ, p. 23
} 
these rights so as not to leave no way for doubt or argument. God had granted life for humans and considered saving it among the main objectives of faith. ${ }^{(51)}$ Such meaning is clearly found in the following verse of Qur'ān:

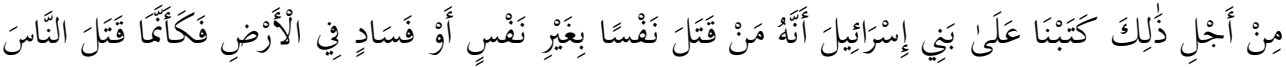

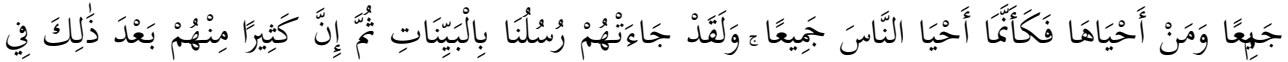

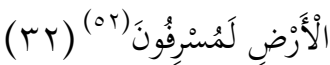

This verse is interpreted as follows: Because of that, we ordinated for children of Israel that if anyone killed a person not in retaliation of murder, or to spread mischief in the land-it would be as if he killed all mankind, and if anyone saved a life, it would be as if he saved the life of all mankind. and indeed, there came to them our messengers with clear proofs, evidences, and signs; even then after that, many of them continued to exceed the limits (e.g. by doing unjust oppression and exceeding the limits set by Allāh by committing the major sins) in the land(32) ${ }^{(53)}$

Full life is protected, and killing is a crime. Even just any transgressing; causing any deterioration is a crime as well, and an aggression deserves revenge, which is decreed for maintaining complete security among people. ${ }^{(54)}$ Such meaning exists in the following verse of Qura'n:

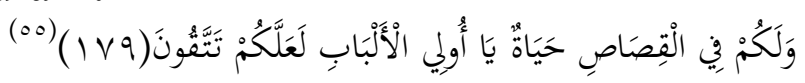

And there is (a saving of) life for you in Al-Qisas (the law of Equality in punishment), $\mathrm{O}$ men of understanding, that you may become Al-Muttaqun (the pious)(179) ${ }^{(56)}$

\footnotetext{
${ }^{(51)}$ Muhammad al-Ghazālī, Huqūq al-Insān bayn Ta'ālīm al-Islām, p. 6-11,46

${ }^{(52)}$ The holy Qur'ān, surat Al-Mā'idah , verse no. 32

${ }^{(53)}$ Muhammad Taqî-ud-Dîn al-Hilālî\& Muhammad Mohsin khān, Translation of the Meanings of the Noble Qur'ān, p. 130, http://www.publications-img.qurancomplex.gov.sa

${ }^{(54)}$ Muhammad al-Ghazālī, Huqūq al-Insān, p. 47

${ }^{(55)}$ The holy Qur'ān, surat al-Baqara, verse no. 179

( ${ }^{56}$ Muhammad Taqî-ud-Dîn al-Hilālî\& Muhammad Mohsin khān, Translation of the Meanings of the Noble Qur'ān, p. 33, http://www.publications-img.qurancomplex.gov.sa
} 
II-Evidences from Qur'ān and Prophetic Sunnah on Freedom of worship

Right faith come from the wise man's recognition for truth, and then his belief in it according to his satisfaction. The Holy Qur'ān mentioned the dissidents and unbelievers in several shapes. But never mentioned forcing anybody to believe in Islam. Islam is never, and will never be, afraid if thousands of other faiths' believers insisting to keep on maintaining their faiths. ${ }^{(57)}$ This meaning exists in the following verses of Qur'ān:

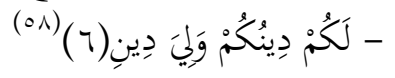

To you be your religion, and to me my religion (Islamic monotheism)(6) ${ }^{(59)}$

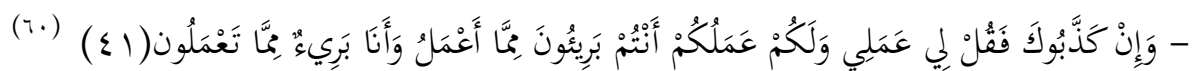

And if they deny you, say: 'For me are my deeds and for you are your deeds! You are innocent of what I do, and I am Innocent of what you do!"(41) ${ }^{(61)}$

Islam did not oblige a Christian or a Jewish to change their beliefs, but asked them to stay on their old faith. It Just did not confront any Muslim believers with any attacks or bad argument, this is stated in the following verse of holy Qur'ān:

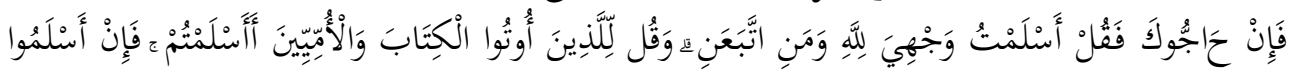

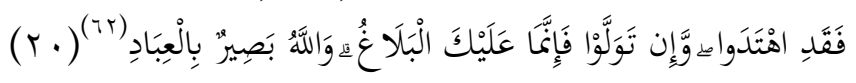

So, if they dispute with you (Muhammad PBUH) say: "I have submitted myself to Allāh (in Islam), and (so have) those who follow me." And say to those who were given the scripture (Jews and Christians) and to those who are illiterates (Arab pagans):

\footnotetext{
${ }^{(57)}$ Muhammad al-Ghazālī, Huqūq al-Insān, p. 72,73

The holy Qur'ān, surat al-kafirūn, verse no. $6^{(58)}$

${ }^{(59)}$ Muhammad Taqî-ud-Dîn al-Hilālî\& Muhammad Mohsin khān, Translation of the Meanings of the Noble Qur'ān, p. 691, http://www.publications-img.qurancomplex.gov.sa ${ }^{(60)}$.The holy Qur'ān, surat Yunus, verse no. 41

${ }^{(61)}$ Muhammad Taqî-ud-Dîn al-Hilālî\& Muhammad Mohsin khān, Translation of the Meanings of the Noble Qur'ān, p. 238, http://www.publications-img.qurancomplex.gov.sa

${ }^{(62)}$ The holy Qur'ān, surat Al-`Imran, verse no. 20
} 
"Do you (also) submit yourselves (to Allāh in Islam)?" if they do, they are rightly guided; but if they turn away, your duty is only to convey the message; and Allāh is All-Seer of (His) slaves. $(41)^{(63)}$

Freedom of worship that Islam ensured to people is unique in all the world. Although Islam used autocracy in several countries, but still bestowing all means of prosperity and survival for all the un believers. ${ }^{(64)}$ Islam is a call for one god, and the believe in Allāh the lord, and respect all the faiths that brought to people with all the prophets and messengers of God. Muslims should believe in prophets Moses and Essa as their believe in prophet Muhammad (PBUH). If any Muslim did not believe in the antecedent prophets or talked badly about; so he is detached. This meaning is precisely reported in the holy Qur'ān, as follows;

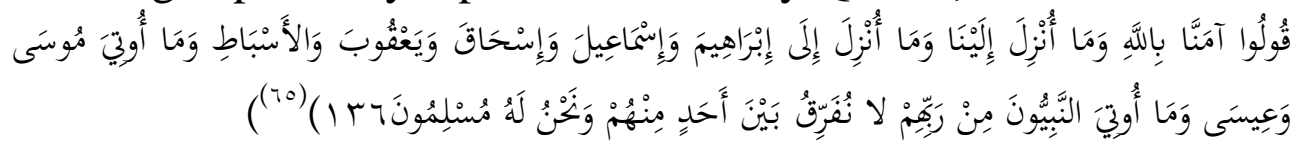

Say (O Muslims), "we believe in Allāh and that which has been sent down to us and that which has been sent down to Ibrāhîm, Ismā'îl, Ishāq, Ya'qūb, and to Al-Asbāt [the offspring of the twelve sons of Ya'qūb], and that which has been given to Mūsā (Moses) and Îsā (Jesus), and that which has been given to the prophets from their Lord. We make no distinction between any of them, and to Him we have submitted ourselves (in Islam).(136) ${ }^{(66)}$

This means that a Muslim should believe in Torah and Bible as supplements for his belief in the final faith; Islam. ${ }^{(67)}$

- The worldwide Report of "Human Rights" in Islam

\footnotetext{
( 63 ) Muhammad Taqî-ud-Dîn al-Hilālî\& Muhammad Mohsin khān, Translation of the Meanings of the Noble Qur'ān, p. 63, http://www.publications-img.qurancomplex.gov.sa

${ }^{(64)}$ Muhammad al-Ghazālī, Huqūq al-Insān, p. 74, 75

${ }^{{ }^{65)}}$ The holy Qur'ān, surat al-Baqara, verse no. 136

( ${ }^{66}$ Muhammad Taqî-ud-Dîn al-Hilālî\& Muhammad Mohsin khān, Translation of the Meanings of the Noble Qur'ān, p. 25, http://www.publications-img.qurancomplex.gov.sa

${ }^{(67)}$. Muhammad al-Ghazālī, Huqūq al-Insān, p. 76
} 
This report had been proclaimed by the Islamic council in December 1981. ${ }^{(68)}$ This report drew attention to Islam and Human rights. It contains a preamble and twenty articles based on Qur'an and prophetic traditions as the main source of Islamic law "Shari'ah". The preamble actually refers to main principals; all human beings are equal and free, there is no discrimination between people according to their race, color, sex, origin, religion, or language. Moreover, it referred several times to the word law, which means that the provisions of this declaration are always subject to rules of Islamic Shari'ah. ${ }^{(69)}$

Formerly, this council had issued the first document "worldwide report", in London in April 1980, including the general review for Muslim system. In Islam, "Human Rights" is not a bonus of a ruler, or a decree of local authority or International Organization. Being from Allah; "Human Rights" are obligatory to be honored. This report was succeeded by a deed on "Human Rights" in Islam; to approve "Human Rights" as base stone for establishing a real Muslim community. "Human Rights" in Islam are varied; right in life, freedom of thoughts, freedom of worship, These are detailed as follows:

\section{- The right in life}

Human life is venerated and no one is allowed to attempt others' lives. ${ }^{(70)}$ This meaning is reported in the following verse of Qur'ān:

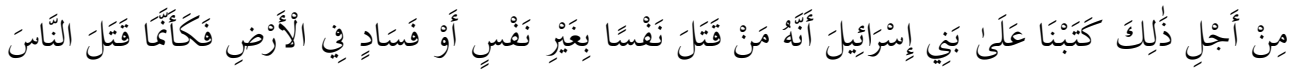

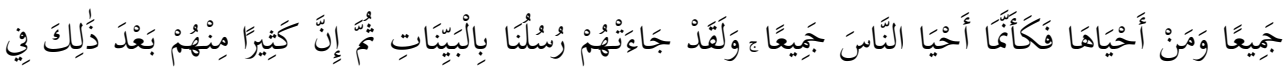

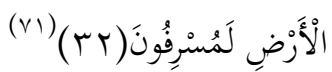

( 68 ) Muhammad Amin Al-Midani, Les Droits de l'Homme et l'Islam, p.103, https://acihl.org/publications.htm?article id=25

${ }^{(69)}$ Lucie Pruvost, "Déclaration universelle des droits de l'homme dans l'Islam et Charte internationale des droits de l'homme", $\quad$ p. 145 , https://www.acihl.org/articles.htm?article_id=5

(70). Muhammad al-Ghazālī, Huqūq al-Insān, p. 210, 212

${ }^{(71)}$ The holy Qur'ān, surat Al- Mā'idah, verse no. 32 
Because of that, we ordinated for children of Israel that if anyone killed a person not in retaliation of murder, or to spread mischief in the land-it would be as if he killed all mankind, and if anyone saved a life, it would be as if he saved the life of all mankind. And indeed, there came to them our messengers with clear proofs, evidences, and signs, even then after that many of them continued to exceed the limits (e.g. by doing unjust oppression and exceeding the limits set by Allāh by committing the major sins) in the land (32) $)^{(72)}$

\section{- The freedom of Thoughts}

Everyone is free to think, and to express his thoughts so long as he maintains the general limits set in accordance to law. Respecting feelings of believers of other faiths is of the Muslims' morals, and no one is allowed to mock at others' beliefs, or to appeal for the support of community against them. The following verse of the Holy Qur'ān declared this.

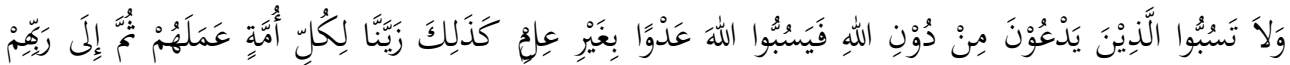

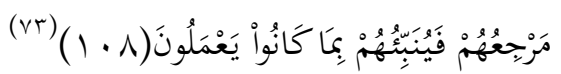

And insult not those whom they (disbelievers) worship besides Allāh, lest they insult Allāh wrongfully without knowledge. Thus we have made fair-seeming to each people its own doings; then to their lord is their return and He shall then inform them of all that they used to $\operatorname{do}(108)^{(74)}$

\section{- The freedom of worship}

Many censures had been directed to freedom of worship in Islam from many aspects, these are;

1. Islam did not allow freedom of worship and Muslims used to unsheathe their swords in face of dissentients to believe in Islam.

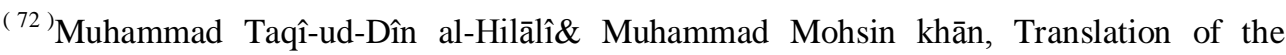
Meanings of the Noble Qur'ān, p. 130, http://www.publications-img.qurancomplex.gov.sa ${ }^{(73)}$ The holy Qur'ān, surat Al- An'ām, verse no. 108

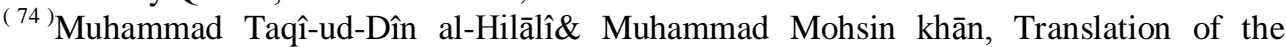
Meanings of the Noble Qur'ān, p. 162, 163 http://www.publicationsimg.qurancomplex.gov.sa
} 
2. Islam prevent discussing other religious beliefs, so prohibit people from choosing their own faith.

3. A Muslim is not allowed to change his faith, and if he did, he should be severely punished, to be killed.

Actually, all these aspects are fault, and did not last in front of clear proofs recurred from experts and scholars concerning this. Religious beliefs connect mankind with his lord, so it is based on complete persuasion, and never done forcibly.

There are statements of several orientalists prove the untruly allegation that Islam had spread by force. Of those; Islam prohibit aggression in several direct verses of Qur'an and some prophetic traditions as well. Besides, Islam condemned all inhumanity and belligerent works. Furthermore, several Muslim countries were reigned by non-Muslim regimes, which allowed missionary organizations to spread Christianity in Muslim countries. Though they could not displace Islam for one step away from these communities' life. ${ }^{(75)}$ On the other hand, in old communities the core of social and political bloc was the unity of religion. Thus, the title foreigner was referring to the one whose religious beliefs differ from the community. As a result, he was considered an enemy and was legal to be killed and his money to be plundered.

On the other hand, a person is attributed to the community if he has the same beliefs, even if he lives in a place remote from that community. Through the medieval times; Europe had forbidden non- Christians from all their rights, except in rare issues. However, Islamic law "Shari'ah" surpassed old positive laws and earlier Holy faiths in protecting equal rights to both Muslims and non-Muslims evenly, with a simple phrase "they had both rights and duties of us as well". (76)

However, according to Islamic law "Shari'ah" non-Muslims who refuse to believe in Islam are freely allowed to live with

\footnotetext{
${ }^{(75)}$ Laura Veccia Vaglieri, Defa' 'An Al-Islam, p. 12

${ }^{(76)}$ Șūfì Hạssan Abū Ṭāleb, Tārikh an-Nuzum al-Qanūniyyah, p. 71,72.
} 
Muslims in their community and become members if they wish. They just had to decree Loyalty to this society and respect its regulations. Actually, the treatment of non-Muslims in Islamic societies and their rights in light of Islamic law indicates the possibility of coexistence of non- Muslims and Muslims. This is ensured under what is known as "Aqd al-Dhimah" non-Muslims contract. Therefore, this confute the views of whom advocate that Islamic societies basically founded on persecuting non-Muslims and forcing them to change their faith. ${ }^{(77)}$ Due to justice by which Arabians were characterized, several Christians believed in Islam; and adopted Arabic as their own language. (78) Therefore, Other orientalists advocated that Islam had widely spread basing on the internal force of Islamic faith and its strong connection with man's intellectual and sensation. ${ }^{(79)}$ Definitely, there were no conquers more merciful and tolerant than the Arabs. ${ }^{(80)}$

As a conclusion, the rights of non-Muslim minorities in the Muslim communities are basically what human rights advocates aspire to for religious minorities and foreigners in modern countries. And that their duties were based on justice. The main source of these rights and duties is Islamic law "Shari'ah", so they are stable and respected. ${ }^{(81)}$ These meanings are definitely reported in Qur'ān; as follows:

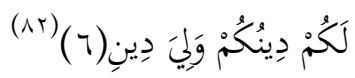

(77)،Abd el-Kareem Zidan, "Mū'āmalat al-Aqaliyyāt ghīr al-Muslima wa al-Ajānib fì alShari'ah al-Islāmīyya", p. 307, http://www.drzedan.com/content.php?id=30

${ }^{(78)}$ Gustave Le Bon, Hadārat al-'Arab, p. 151

${ }^{(79)}$ Ja'far 'Abd el-Salām, "Huqūq al-Insan fī al-Islam” a research presented in a colloquium entitled "al-Islam fī Sharq Asia, Hadārah wa Mū'āsrah", Taipei, Taiwan, 1425 A.H/ 2003 A.D, p. 33

${ }^{(80)}$ Gustave Le Bon, Hadārat al-`Arab, p. 151

(81) 'Abd el-Kareem Zidan, "Mū'āmalat al-Aqaliyyāt ghīr al-Muslima wa al-Ajānib fì alShari'ah al-Islāmīyya", p. 307, http://www.drzedan.com/content.php?id=30

${ }^{\left({ }^{82}\right)}$ The holy Qur'ān, surat Al- Kafirun, verse no.6 
To you be your religion, and to me my religion (Islamic monotheism) $(6)^{(83)}$

-Evidences from the Holy Qur'ān and Prophetic traditions (hadiths):

\section{Holy Qur'ān}

Several verses of the Holy Qur'ān are assuring each one's freedom of worship. These verses, as part of the Holy Qur'ān; are the speech of Allāh. Thus; whenever any human does not comply, he is a disobedient. Such extremist attitudes are not to be the defect of Islam. Examples of these verses as follow:

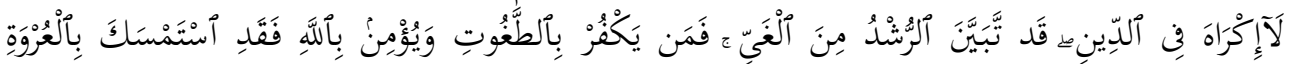

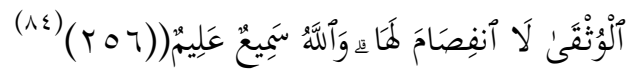

There is no compulsion in religion; Verily, the right path has become distinct from the wrong path. Whoever disbelieves in Tāghūt (evil) and believes in Allāh, then he has grasped the most trustworthy handhold that will never break. And Allāh is AllHearing, All-Knower(256) ${ }^{(85)}$

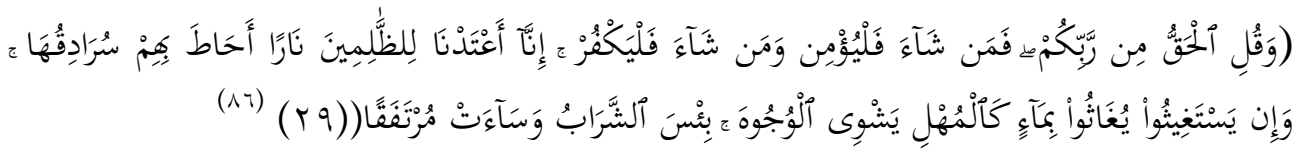

And say, "The truth is from your Lord. Then Whoever willslet him believe. And whoever wills-let him disbelieve". Verily, we have prepared for the Zälimūn (polytheists and wrong-doers) a Fire, whose walls will be surrounding them (disbelievers in the oneness of Allāh). And if they ask for help (relief, water), they

\footnotetext{
${ }^{(83)}$ Muhammad Taqî-ud-Dîn al-Hilālî\& Muhammad Mohsin khān, Translation of the Meanings of the Noble Qur'ān, p. 691, http://www.publications-img.qurancomplex.gov.sa ${ }^{(84)}$ The holy Qur'ān, surat Al- Baqarah, verse no.256

${ }^{(85)}$ Muhammad Taqî-ud-Dîn al-Hilālî\& Muhammad Mohsin khān, Translation of the Meanings of the Noble Qur'ān, p. 52, http://www.publications-img.qurancomplex.gov.sa (86) The holy Qur'ān, surat Al- Kahaf, verse no.29
} 
will be granted water like boiling oil, that will scalds their faces. Terrible is the drink, and evil Murtaqaf (resting place)(29) ${ }^{(87)}$

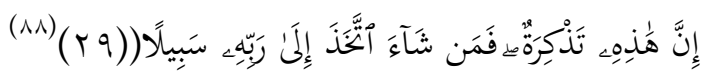

Verily, this (verse of the Qur'ān) is an admonition, so whosever wills, let him take a path to his Lord (Allāh)(29)

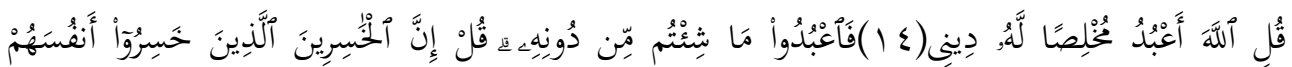

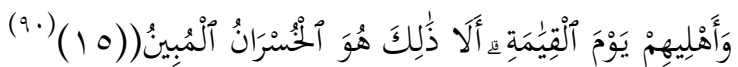

Say (O Muhammad): Allāh alone I worship by doing religious deeds sincerely for his sake only(14)So worship what you like besides Him. Say (O Muhammad): The losers are those who will lose themselves and their families on the Day of Resurrection. Verily, that will be a manifest $\operatorname{loss}(15)^{(91)}$

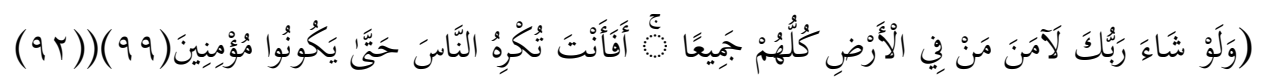

And had your Lord willed, those on earth would have believed, all of them together. So, will you (O Muhammad): then compel mankind, until they become believers (99)

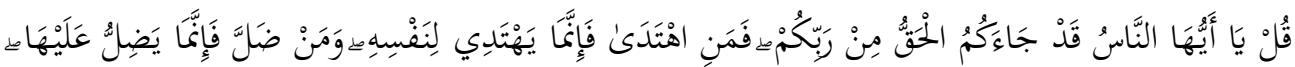

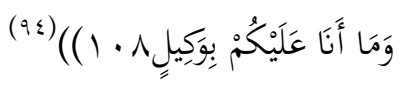

Say: "O you mankind! Now Truth (i.e the Qur'ān and prophet Muhammad) has come to you from your Lord. So whosoever

\footnotetext{
${ }^{(87)}$ Muhammad Taqî-ud-Dîn al-Hilālî\& Muhammad Mohsin khān, Translation of the Meanings of the Noble Qur'ān, p. 331, 332, http://www.publicationsimg.qurancomplex.gov.sa

${ }^{(88)}$ The holy Qur'ān, surat Al- Insān, verse no.29

${ }^{(89)}$ Muhammad Taqî-ud-Dîn al-Hilālî\& Muhammad Mohsin khān, Translation of the Meanings of the Noble Qur'ān, p. 652, http://www.publications-img.qurancomplex.gov.sa

${ }^{(90)}$ The holy Qur'ān, surat Az-Zumar, verses no.14, 15

( 91 ) Muhammad Taqî-ud-Dîn al-Hilālî\& Muhammad Mohsin khān, Translation of the Meanings of the Noble Qur'ān, p. 511, http://www.publications-img.qurancomplex.gov.sa ${ }^{\left.{ }^{92}\right)}$ The holy Qur'ān, surat Yūnus, verse no.99

${ }^{(93)}$ Muhammad Taqî-ud-Dîn al-Hilālî\& Muhammad Mohsin khān, Translation of the Meanings of the Noble Qur'ān, p. 244, http://www.publications-img.qurancomplex.gov.sa ${ }^{(94)}$ The holy Qur'ān, surat Yūnus, verse no.108
} 
receives guidance does do so for the good of his own self; and whosoever goes astray, he does so his own loss; and I am not (set) over you as a Wail (disposer of affairs to oblige you for guidance) $(108)^{(95)}$

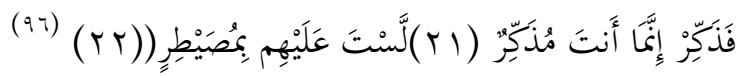

So, remind them (O Muhammad)- you are only one who

reminds(21)You are not a dictator over them $(22)^{(97)}$

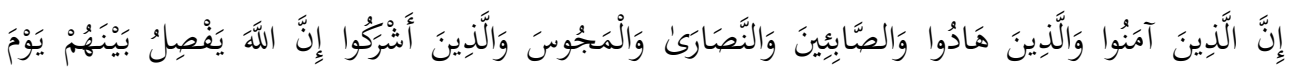

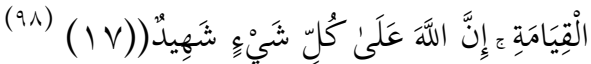

Verily, those who believe (in Allāh and his messenger Muhammad), and those who are Jews, and the Sabians, and the Christians, and the Majūs (Magians), and those who worship others besides Allāh, truly, Allāh will judge between them on the Day of Resurrection. Verily, Allāh is over all things a witness $(17)^{(99)}$

\section{-Prophetic Traditions}

Although there are several prophetic traditions "hadith-s" in the course of freedom of worship, they are barely known. On the contrary; other traditions "hadith-s" in forcing of worship are widely known. The latter are only two; one is weak and invalid text, and the other, is interpreted in means of fighting.

The $1^{\text {st }}$ hadith is that of 'Ekrema on behalf of ibn 'Abas stated: "who changes his religion should be killed" literally (mn badal dinūh fa iqtüllūh). Only 'Ekrema, the slave of ibn 'Abas who was of the dissidents, narrated this tradition. He narrated it in course

\footnotetext{
( 95 ) Muhammad Taqî-ud-Dîn al-Hilālî\& Muhammad Mohsin khān, Translation of the Meanings of the Noble Qur'ān, p. 245, http://www.publications-img.qurancomplex.gov.sa ${ }^{(96)}$ The holy Qur'ān, surat Al-Ghāshiyah, verses no.21, 22

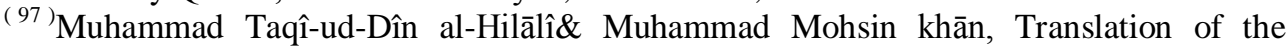
Meanings of the Noble Qur'ān, p. 675, http://www.publications-img.qurancomplex.gov.sa ${ }^{(98)}$ The holy Qur'ān, surat Al- Hajj verse no. 17

${ }^{(99)}$ Muhammad Taqî-ud-Dîn al-Hilālî\& Muhammad Mohsin khān, Translation of the Meanings of the Noble Qur'ān, p. 375, http://www.publications-img.qurancomplex.gov.sa
} 
of the story of burning the apostates by Imam 'Ali ibn Abi Talib (may god blesses him). This incident was not proven to have happened. Only 'Ekrema recited it. Because 'Ekrema was of the dissidents, who agreed with killing Muslims if they quitted their faith, such hadith, if true, would be an argument for them to declare killing Muslims.

The other Hadith is of ibn Mas'ud, who stated that: "killing a Muslim is not allowed except in three cases. Among them is the one who deserted his faith and detached his community". This may correspond with the Holy Qur'ān interpretation for the one who deserted his faith and detached his community resulting in spoiling of his community. ${ }^{(100)}$ However, prophetic traditions in freedom of worship are numerous and correspond to verses of Qur'ān in the same course. The following reflect the most important evidence proving this notion:

- Al- Madina document in which prophet Muhammad (PBUH) considered the people residing in Al- Madina all as one nation "umah" against others although they were a mixture of Muslims, Jewish, and pagans as well.

Jihad was based on fighting enemies, not those of different faith. Besides, the document conforms with Sunni signification. The document is the most famous deed. It has several names: AlMadina document (deed of Al-Madina), Al-Madina paper (leaf). It was concerned with people of Al-Madina and all those who were associated with the Muslims and non-Muslims as well. This deed refers to combining non-Muslims with the Muslims' community to form a nationalism unity and contributing defense. This document includes fifty clauses. It is a distinct juristic deed. ${ }^{(101)}$ Of these, the $12^{\text {th }}$ clause which stipulates: "whoever follows us from the Jews, he has the same rights in sponsorship and pattern, and will not maltreated. He will be given priority like others". Furthermore, the $23^{\text {rd }}$ clause which stipulates: "the Jews

\footnotetext{
${ }^{(100)}$ Hassan ibn Farhan al-Malki, Hūrayyāt al-I'tiqād, p. 86, 87

${ }^{(101)}$ Hassan ibn Farhan al-Malki, Hūrayyāt al-I'tiqād, p. 113, 114
} 
are allowed to spend money together with Muslims once they are at war". The $24^{\text {th }}$ clause stipulates: "the Jews of Beni 'Ouef are one nation with the Muslims; the Jews with their faith and Muslims with theirs as well'. In addition, they are both free in regard to their slaves and themselves, except who maltreats others or commits a sin. This causes damage to himself and his household".

In conclusion, this deed refers to advocating justice not defending a faith at the expense of others, or a nation over others. It arouses the interest in Islam and, inclusively, calling for it, but it is neither a compulsion nor a condition set forward to be a contributor to the deed. Such human right deeds related to Islam are more firm and secure than those propagated in wide spread hadith-s and claiming the prevention of diversity of faiths in Muslim's community. This deed is associated with the Jews who were and still aggressive to the believers in Islam. Although the Jews were the minority, and it was easy to expelling them from the decree, prophet Muhammad (PBUH) was not to behave in this manner.

- Prophet Muhammad's (PBUH) decree (firman) to the Christians of Nijran towards the end of prophetic era, it refers to the prophet's promise to protect their churches, fortunes, and their freedom of worship.

- Prophetic traditions where prophet Muhammad produced himself to tribals with proofs on their freedom of worship.

\section{Recent behaviors against "Human Rights" in the name of Islam}

What happens today against "Human Rights" is under laying the insignia of standing up for the patronage of Islam. The last few decades showed the rise of numerous extremist troops with bad behaviors against non-Muslims. Therefore, they have a great

\footnotetext{
${ }^{(102)}$ Hassan ibn Farhan al-Malki, Hūrayyāt al-I'tiqād, p. 88, 117, 123

${ }^{(103)}$ Abū Na'im Al- Asbāhāni, Dalāīl an-Nūbuah, p. 251
} 
effect in defaming Islam. Of these nowadays are the extremists in Iraq and Levant (Syria), who are widely known as Islamic State in Iraq and Levant (Syria), briefly entitled ISIL or ISIS. These troop had expanded rapidly and had control over numerous areas. They apparently hold the standard of patronage of Islam and Sunni rites in particular. ${ }^{(104)}$

These troops' main purpose was to overcome the ruling regimes and to replace with an Islamic state (a theocratic regime), formerly known as caliphate "khīlāfah". Their thoughts are mainly originated from writings of Ibn Taymìyah, ${ }^{(105)}$ and the believers in the Wahhabiyyah ${ }^{(106)}$ movement. These troops believe in the thoughts of the ancestral "Salafi" jihadism but with more violence.

All the writings and spokesmen of these troops' members refer to racialism. They persecuted all believers of other faiths; such as Christians, and Yazidis. Furthermore, they persecuted Muslims of other sects such as kurdish, and Shi'ites as well. According to ISIS, those considered apostates and deserved to be killed. ${ }^{(107)}$

This troop (ISIS) had committed horrible actions, which had major effect all over the world. They used to record live videos for slanting, burning, and cutting heads of living people in an inhumane unprecedented way. Unfortunately, their simulated affiliation to Islam, and their fictitious arrogation for applying its

\footnotetext{
${ }^{(104)}$ Māzin Shandab, Dā'īsh, Māhīyatūh, Nashātūh, p.11-16.

${ }^{(105)} \mathrm{He}$ is Taq̄i al-Dīn Abū al-'Abbās Aḥmad ibn 'Abd al-Salām ibn 'Abd Allāh ibn Muhammad ibn Taymiyyah (born 1263, Harran, Mesopotamia-died September 26, 1328, Damascus, Syria). He is one of Islam's most forceful theologians, as a member of the Pietist school founded by Ibn Hanbal, sought the return of the Islamic religion to its sources: the Qur'ān and the sunnah, revealed writing and the prophetic tradition. He is also the source of the Wahhābiyyah, a mid-18th-century traditionalist movement of Islam. http://academic.eb.com/levels/collegiate/article/Ibn-Taymiyyah/41931

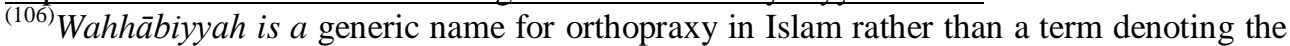
specific group. This group emerged in al-Hejaz, now Saudi Arabia in the $18^{\text {th }}$ century. http://academic.eb.com/levels/collegiate/article/monasticism/109510\#38692.toc

${ }^{(107)}$ Cole Bunzel, from paper state to caliphate:(the ideology of the Islamic state), p. 9,10
} 
percepts, resulted in making Islam one of the most controversial faiths associated with terrorism. (108)

\section{Manuscripts and archaeological documents referring to freedom of worship in Islam}

Evidences on freedom of worship are multiple; these are varied in prophetic covenants and document, khedives' decrees (Firmans), monumental artifacts, etc. The following lines discuss samples evidences briefly.

- Documents

Prophet Muhammad's Covenant held among the immigrants "Mūhājerīn", proponents "Anșār", and the jewish "yahūd", which is known as the country constitution "Dūstūr". This document was disposed to arrange the relation between the Islamic State inhabitants, actually the Madina residents at that time. With the advent of Prophet Muhammad (PBUH) to Al-Madina, the inhabitants were of both; Arabs and Jewish. ${ }^{(109)}$

Late historians such as Sheikh Muhammad Al-Ghazali named this document as a constitution "Dūstūr". He dealt with this document from a constitutional view. Hence, it was a law for the recent Islamic State. It consists of several items aim to arrange the relation between community variant classes, and declare their rights and duties as well. ${ }^{(110)}$ Moreover, others are agree with naming this document as "constitution", as it more proper to with the modern era. ${ }^{(111)}$ Several dates are specified to refer to this document's time. It was dated before Badr Expedition "Ghazwat Badr", others stated to be written after Badr Expedition. ${ }^{(12)}$

Ibn Ishạa stated that "Prophet Muhammad (PBUH) set up a treaty between the immigrants "Mūhājerīn" and the proponents "Anșāre". Prophet Muhammad reconciled with the Jewish and promised them to keep on their believe in Judaism, and save their

\footnotetext{
${ }^{(108)}$ Sāmir Abū Rūmān, Dā’̄ish: Tanzīm al-Dawla fì 'Ūoon al-Shū’ūb, p. 5

${ }^{(109)}$ Jāsim Muhammad Rashid al-'Esawy, al-Wāthīqa an-Nabawīyyah, p. 19

${ }^{(110)}$ Jāsim Muhammad Rashid al-'Esawy, al-Wāthīqa an-Nabawīyyah, p. 29

${ }^{(111)}$ Muhammad Sa'̄̄d Ramadan Al-Būty, Fiqh as-Sirah, p. 160

${ }^{(112)}$ Jāsim Muhammad Rashid al-'Esawy, al-Wāthīqa an-Nabawīyyah, p. 41
} 
money as well. ${ }^{(113)}$ Some of the later authors divided the document into 47 items and numbered them continuously based on the text mentioned by Ibn Ishāq. ${ }^{(114)}$

- Prophet Muhammad's message to selcareH, the mighty of the Romans, as follows:

بسم الله الرحمن الرحيم من يُمَّمَّ رسول الله إلى هرقل عظيم الروم: سلام على من اتبع الهدى، أما بعد: فإِني

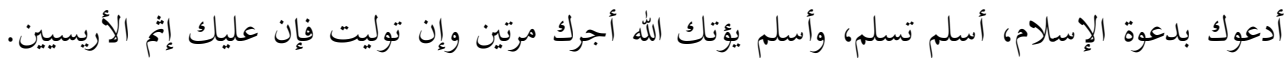

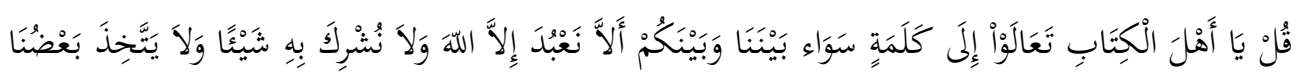

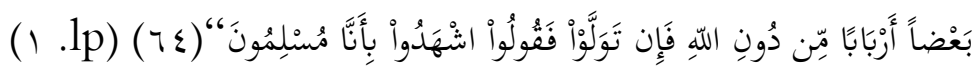

- Prophet Muhammad's message to people of Maqnā

This is one of the famous letters of prophet Muhammad (PBUH) to Hanina and people of Kheibar and Maqnā and their progeny found within Cairo Genizah documents (Pl. 2). ${ }^{(115)}$ It is dated to the $3^{\text {rd }}$ of Ramadan in the fifth year of Hegira. The main content of this letter is to promise the non-Muslims, the Jews in particular, to secure and bestow the protection of Allāh and his messenger with regard to their communities, beliefs and properties (pl. 3). ${ }^{(116)}$

- Several Arabic and Turkish covenants are kept in the library of Saint Catherine Monastery in Sinai. Of these:

1. A Turkish copy of Prophet Muhammad's covenant to Christians (pl. 4).

2. An Arabic decree (Firman) signed by Divan Misr al-Mahrusa with Muhammad Ali Pasha seal (pl.5).

\footnotetext{
${ }^{(113)}$ Ibn Hīshām, as-Sirrah an-Nabawīyyah, 1/571

${ }^{(114)}$ Muhammad Hamīd Allāh, Majmū'at al-wathā'q al-Siyāsīyah, p. 57-64

${ }^{(115)}$ The word Genizah literally means store house or burial place, and describes a special place was designated to store documents of all sorts not simply those containing God's name which were not supposed to be destroyed. It comprised a huge number of texts estimated at about 250.000 manuscript are invalid books and valuable manuscript leaves.

-Tasha Voederstrasse \& Tanya Treptow, A cosmopolitan City Muslims, Christians, and Jews in Old Cairo, p. 27

${ }^{(116)}$ Hartwig Hirschfeld, "The Arabic Portion of the Cairo Genizah at Cambridge", p. 167181, http://www.jstor.org/stable/1450432

${ }^{(117)}$ Turkish Covenant, Roll no. 4
} 


\section{- Monumental Artifacts}

1. One of the main evidences of religious tolerance and peaceful coexistence between Muslims and adherents of other faiths is reflected in those adherents seeking their help as reflected in several artistic works such as architectural and decorative arts. A template of these is a wooden door riveted with silver. This door was transported from the mosque of Sayyidah Zainab to the Museum of Islamic Art (Record no. 3737). This artifact dates back to the $13^{\text {th }}$ century A.H/19 ${ }^{\text {th }}$ century A.D. This masterpiece (pl. 6) is signed by a Jewish craftsman who is "Yahüda Aslān". This is a vivid testimony of Muslims' tolerance towards adherents of other faiths. ${ }^{(119)}$

2. Another image of peaceful coexistence stumbles upon two copper chandeliers with Arabic calligraphy within the Jewish Ben 'Ezra Synagogue (Pl. 7), ${ }^{(120)}$ in the region of religious complex "Mujama' al-Adiān" in Old Cairo (Fustat). ${ }^{(121)}$ One of these chandeliers is hung down to the right of the Alter bearing names of the four orthodox Caliphs written in Arabic letters (pl.8). Other chandelier is a conical shape of copper, hung down from the building's ceiling and bearing the name of Sultan Al-Manșoūr Qalawoūn written in Arabic letters as well (Pl.9).

3. Monochrome lustre-painted bowl fragment inv. No. 5397/1, preserved in Cairo, museum of Islamic art (pl.10), excavated at Fustat. It is attributed to Fatimid epoch $\left(5^{\text {th }}-6^{\text {th }}\right.$ century A.H/ $11^{\text {th }}$

\footnotetext{
${ }^{(118)}$ Arabic firman, Roll no. 175

${ }^{(119)}$ Bernard O'kane, and others, The illustrated Guide to the Museum of Islamic Art, p. 260, 261

${ }^{(120)}$ The word synagogue is known in Greco Hellenistic as "synagoge" which means the group. It equals the hebrew term "Keneseth". Later it was used as a title for places of jews assembly called "beth Hakeneseth" meaning house of prayer.

The universal Jewish Encyclopedia, p. 120

${ }^{(121)}$ Ben Ezra Synagogue was originally a church called "kanisat al-Shamiyyin" the synagogue of Syro-Palastinians. it stands in line of Qasr al-Shama' in old Cairo. It was built in 336 A.D as carved in hebrew letters on its wooden door. Moreover, it was stated that this place housed a copy of Torah written by Prophet Ezra, who is known in Arabic as al'Uzayr.

Al-Maqrīzī, Al-khitatat, Vol. III, p. 498

(122)، Āīsha Al-Tūhāmy, Jawālāt Siyahiyyā baīn Āthār al-Qāhira, p. 31
} 
- $12^{\text {th }}$ century A. D). This fragment is decorated with a man's head surrounded by a three-rimmed halo, displaying part of a cross. This human face mostly resembles Jesus Christ. He is displayed bearded and has long curled hair tresses around his shoulders. Fingers of his right hand are just visible at the bottom,

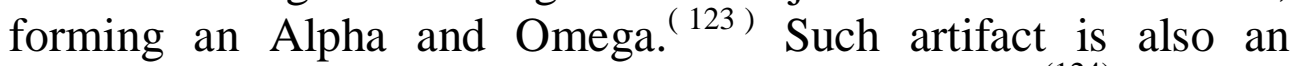
evidence of Muslim's tolerance towards Christianity.

4. Ceramic under-glazed painted fragment, no. 13174 preserved in Cairo, museum of Islamic art (pl.11), Egypt or Syria, dated back to $7^{\text {th }}$ century A.H/ $13^{\text {th }}$ century A.D. This fragment is a part of a plate of which two other fragments are preserved in the Benakhi Museum in Athens and depicts the apostles of Jesus Christ. The existing fragment is decorated with the scene of descending Jesus while leaning on Virgin Mary. This piece is of unique historical value as an undeniable physical evidence of Muslim's tolerance to other faiths. Although some earlier studies dated this artifact to the Ayyubid epoch; the most recent analyses have suggested that it may be attributed to a later-Mamlukdate. $^{(125)}$

5. Another sign for Muslim's tolerance to other faiths during the Ayyubid epoch is the applying of Christian scenes and topics from the holy Bible on Ayyubid Metalwork. Of these are the scenes the Baptizing of Jesus Christ, his accession (entry) to Jerusalem, his birth and circumcision, beside other scenes. ${ }^{(126)} \mathrm{A}$ distinctive sample of this is a canteen of brass inlaid in silver no. F1941.10 preserved in Freer Gallery of Arts, Washington (pl.12). This artifact was attributed to Syria, mid of the $7^{\text {th }}$ century A.H/

${ }^{(123)}$ Alpha (a or A) \& Omega ( $\omega$ or $\Omega$ ) are the first and last letters of the Greek alphabet. The letters together represent the eternal nature of the Christ. This has been derived from the statement said by Jesus (or God) himself "I am Alpha and Omega, the First and the Last, the Beginning and the End".

The king James Version of The Holy Bible, p. 721, chapter 22 revelation, statement $\{22: 13\}$ http://www.bookbindery.ca/KJBIBLE.pdf

${ }^{(124)}$ Bernard O'kane and others, The Illustrated Guide to the Museum of Islamic Art, p. 59

${ }^{(125)}$ Bernard O'kane and others, The Illustrated Guide to the Museum of Islamic Art, p. 112

(126)،Abd el-Aziz Șalāh Sālem, Al-Funūn al-Islamiyya, p. 280 
$13^{\text {th }}$ century A.D. It is adorned with several scenes, among them is the Baptism. This scene is divided into two parts; the upper part depicts the virgin Mary wearing long garment, and a halo surrounding her head, Jesus Christ is depicted as a child sleeping within a closed box. Mary is shown while going to lift the box's lid. Three animals are apparent in the scenes background; those mostly donkeys. On the opposite side is a drawing of a winged angel approaching towards him. The lower part depicts Jesus Christ as a child, seated within a big bowl, two persons flanking him; one is pouring water over his body, while the other one is washing him. A group of persons, animals, and birds are included as well. ${ }^{(127)}$ The same object includes scene of Jesus Christ's accession to Jerusalem. He occupies the central part while riding on the back of a donkey, three children (two of them holding palm fronds and the third is catching a cross) are coming towards him. Near the procession, there are two persons standing before a domed structure. Two angels in shape of winged human shapes are occupying the scene's upper part.

6. A brass basin inlaid with silver, no. F1955.10 preserved in Freer Gallery of Arts, Washington (pl. 13). Probably attributed to Syria, dated back to 659-669 A.H/1239-49 A.D. This basin is designed for the Ayyubid Sultan al-Malik al-Salih Ayyub. ${ }^{(129)}$ It displays Jesus Christ while resurrecting dead. This scene is applied within a lobed shape, where Jesus Christ is depicted accompanied by one of his students, while wearing religious sackcloth and consecration halo around their heads. They are coming towards a tomb. Jesus is stretching his right arm towards the dead, while catching a stick on his left arm. ${ }^{(130)}$ This basin also includes the scene of Jesus Christ's entry to Jerusalem. The

\footnotetext{
${ }^{(127)}$ Ranee A. Katzenstein \& Glenn D. Lowry, "Christian Themes in Thirteenth-Century Islamic Metalwork", p. 55,56

${ }^{(128)}$ Ranee A. Katzenstein \& Glenn D. Lowry, "Christian Themes in Thirteenth-Century Islamic Metalwork", p. 61

${ }^{(129)}$ Esin Atil, Art of the Arab world, p. 65-68

${ }^{(130)}$ Eva Baer, Metalwork in Medieval Islamic Art, fig. 67
} 
scene is applied within a lobed shape, where Jesus Christ is depicted riding on the back of a donkey and catching a palm frond stick. Jesus is flanked by two persons; One stands before the donkey shaking hands with Jesus, while the other person stands towards the donkey's back opening his arms welcoming the arrival of Jesus. All are wearing the religious sackcloth with consecration halos around their heads. ${ }^{(131)}$ Annunciation scene is occupying part of this basin. One of its lobed shapes depicts the Virgin Mary seated and looking to the left to hearing Gabriel who is depicted in the form of a winged human shape. consecration halos are surrounding their heads.

7. Distinct evidence of Muslim's peaceful coexistence with adherents of other faiths is the mixture of artistic elements of these faiths together. This is attested in a plaque of ivory, inv. No. 5620, preserved in Cairo, museum of Islamic art (pl.14). it is attributed to the Mamluk epoch $8^{\text {th }}$ century A.H/14 ${ }^{\text {th }}$ century A.D. This object's wooden frame has a groove and tenon, indicating that it was a part of a larger composition, such as a door. The unique form is the decorative elements of a central large cross sign on a delicate intersecting arabesque background. The cross in this plaque's center makes it likely that it had adorned a Christian building, while the carving of the intersecting arabesques can be paralleled in mosque furnishings such as minibars or Qur'an stands. ${ }^{(133)}$

${ }^{(131)}$. Eva Baer, Metalwork in Medieval Islamic Art, fig. 66

(132). Howard C. Hollis, “An Arabic censer”, p. 137, 138

${ }^{(133)}$ Bernard O'kane and others, The Illustrated guide to the museum of Islamic Art, p. 332 


\section{Conclusion}

- There are several interpretations of the term "Human Rights" which differs according to societies and cultures.

- After World War II, some old democratic regimes began to apply "Human Rights" before the rise of the term itself. However, it evidently exists among the supreme values and principles of the holy faiths; Judaism, Christianity, and Islam. Thus, they were the first who had called for these rights.

- This research discussed the term "Human Rights" from several sources; international, local, and religious ones.

- Although there are several sources of "Human Rights"; it is become clear that it is not an outcome of western civilization, but it is deeply rooted from the Holy faiths and particularly among the fundamentals of the Islamic Faith about twelve centuries earlier than the West addressed the issue.

- Islamic faith was the first to consider freedom of worship a fundamental right for mankind.

- Several verses of the Holy Qur'ān besides prophetic traditions presented diverse demonstrations on Islamic faith's tolerance with dissidents and the disbelievers.

- Unfortunately, some extremist troops, such as Jabhat anNusrah, ISIS, etc. had come into sight since the last decade in the $20^{\text {th }}$ century A.D.

- Those extremists believe in the thoughts of Salafi jihadism doctrine but with more violence. They considered themselves representative of Sünnah, and freely proscribed and seized Jews, Christians, Kurds, Yazidis, and Shi'ites. Thus, Islam became the most controversial faith, and is wrongly associated with terrorism.

- However, the Islamic faith is seen innocent of all aggressive behaviors of killing, slanting, burning, etc. committed by those extremists in the name of Islam.

- Once the main aim of this paper is to emphasize Islamic faith's assurance of freedom of worship, several verses of the Holy 
Qur'ān and prophetic traditions are utilized to confirm that the Islamic faith never attempted forcing anybody to believe in Islam. In addition, it emphasizes that while Islam is a call for belief in the unique God, it respects all faiths brought to people by all the prophets and messengers of Alläh. Thus, Muslims should believe in Torah and Bible as a supplement for their belief in Islam.

- Another type of evidence on Islamic faith's innocence of terrorism was represented in a Turkish copy of Prophet Muhammad's (PBUH) covenant to Christians, beside security decrees (Firmans) given from several khedives to the Monks of Saint Cathrine Monastery in Sinai.

- Furthermore, the presented masterpieces are giving an image of Islam's peaceful coexistence with adherents of other faiths. Of these, the wooden door (of the mosque of Sayyidah Zainab) signed by its Jewish craftsman "Yahūda Aslān". In addition, there are two copper chandeliers of Sultan Al-Manșoūr Qalawoūn within Ben 'Ezra synagogue in old Cairo.

- Another sign for Muslim's tolerance to other faiths during the Ayyubid epoch is the applying of Christian scenes and topics from the holy Bible on Ayyubid Metalwork. Of these are the scenes the Baptizing of Jesus Christ, his accession (entry) to Jerusalem, his birth and circumcision, beside other scenes.

- Reviewing all these evidences, and tracing the rise of "Human Rights" term and application are sufficient to prove the Islamic faith's innocence of all aggressive behaviors of extremists, such as ISIS and others.

-While the core stone of the Islamic law "Shari'ah" depends on the equality between people, several non-Muslim countries did not make justice. In addition, modern political ethics are utilitarian. Therefore, in many cases countries make themselves deaf to the suffering of vulnerable minorities as long as they have good relations with the unjust countries. In conclusion, the whole world is responsible for these minorities as it is a moral issue. 
- Moderate Religious institutions all over the Islamic World such as the Holy Institute of $A l$-Azhar should make more effort to widely spread out the concepts of orthodox "true" Islamic Faith.

- Focusing on the idea that either a Muslim believer or a group of Muslims when committing any extreme aggressive behaviors are not - God forbid-a defect in Islam. It is needed to remember that there are extremists who believe in Judaism, Christianity, or atheists all over the world whose actions are not as heighted as those of Muslims. 


\section{Bibliography:}

The Holy Qur'ān

\section{Arabic Sources}

- Abū Na'im Al- Asbāhāni, Dalāīl an-Nūbuah, taḥiq Muhammad Rawās Qal'aji\&

'Abd el-Bar 'Abās, 2Vols.,Dar an-Nafāis, $2^{\text {nd }}$ edit., Beirut, 1406A.H/ 1986A.D

- Al-Maqrīzī (Aḥmad ibn 'Ali ibn 'Abd El-Qādir died in 845 A.H/ 1441 A.D), AlMawā'iz wa al-'Etibār be-Zikr Al-khițat wa al-Athār, vol. III, Bulaq, 1270 A.H

- Arabic firman, Roll no. 175, dimensions 32.5x21 C.M, Library of Supreme Council of Culture, Cairo.

- Ibn Hīshām (Muhammad ibn 'Abd al-Malik), as-Sirrah an-Nabawīyyah, Taḥqīq Mūṣtafa as-Saqah, Ibrāhīm al-Ibyārī, and 'Abd el-Hāfḍh Shalabī, Dar al-Fikr, Beirut, 1986

\section{Arabic References}

- 'Abd el-Aziz Șalāh Sālem, Al-Funūn al-Islamiyya fĩ Al-'Așr Al-Ayyubi, Vol.1, al-Tuhaf al-Ma'daniyya, $1^{\text {st }}$ edit., Markaz al-Kittāb li al-Nashr, 1999

- 'Abd el-Kareem Khalifa, al-Qānun ad-Dawlī lī-Ḥuqūq al-Insān, Alexandria, 2013

- 'Abd el-Kareem Zidan, "Mū'āmalat al-Aqaliyyāt ghīr al-Muslima wa al-Ajānib fī al-Shari'ah al-Islāmīyya", majalat al- Huqūq al-Kuwaittiyya, vol.7, issue no. 3, zu al-Hijja 1403A.H/ Sep. 1983 A.D, http://www.drzedan.com/content.php?id=30- 43-2018

- Ad-Dalil al-'Arabi ḥawl Ḥuqūq al-Insān wa al-Tanmiyyah, , al- Mūnazamah al'Arabiyyah li Ḥuqūq al-Insān bī al-ta'āwn ma'a maktab al- mūfawa ̣̦ as-Sami $\overline{1}$ Ḥuqūq al-Insān wa bernamaj al-ūmam al-Mūtahida al-Inmāīi, $1^{\text {st }}$ edit., Cairo,2005

- Aḥmad Abū Al-Wafā, al-Hīmāyah ad-Dawlīyyah lī Huqūq al-Insān fì İtar mūnazamat al-ūmam al-Mūtahida wā al-Wīkalat al-Dawliyya al-Mūtakhașiṣah, $1^{\text {st }}$ edit., Cairo, 2000

- Aḥmad ar-Rashīdī, 'Adnān Hūsseīn, Ḥuqūq al-Insān fi al-Watan al-'Arabī , $1^{\text {st }}$ edit., Dār Al-F̄̄kr, , Damascus, 2002

- ‘Āīsha Al-Tūhāmy, Jawālāt Siyahiyyā baīn Āthār al-Qāhira al-Qibțīyya wa alIslāmiyyah, Dar al-'Ālam Al-'Arabi, Cairo, 2010

- 'Ali Al-Na'ūq, Ḥuqūq al-Insān, (w.p.),1994

- 'Ali Al-Shūkrī, Ḥuqūq al-Insān fi Dhh̄īl al-'Awlamah, $1^{\text {st }}$ edit., Amman, 2006

- 'Ali Muhammad Ad-Dabās, 'Ali 'Eliān Abū Zaied, Ḥuqūq al-Insān wa Ḥūriyātūh wa dūr shar'yat al-Ijrā'āt al-Shūratiyya fī ta'zizaha, Dar ath-Thaqāfah, Jordon, 2011

- Al-Shafí'i Muhammad Bashīr, Qānūn Ḥuqūq al-Insān.. Mașāderūh wa Taṭbiqātūh al-Wataniyyah wa ad-Dawliyyah, Alexandria, (w.d.) 
- 'Attīyya khalīl 'Attiyya, Asāssiyyāt fì Ḥuqūq al-Insān wa at-Tarbiyya, $1^{\text {st }}$ edit., Amman, 2011

- Claudio Zanghi, al-Ḥīmāyyah al-Dawlīyya lī Ḥuqūq al-Insān, translated by Fawzi 'Essa, $1^{\text {st }}$ edit., Lebanon, 2006

- David Wesburdn and others, mukhtārāt mn Adāwāt Ḥuqūq al-Insān al-Dawliyya.. wa biblographia lī al-bahth fĩ al-Qānūn al-Dawli lī Ḥuqūq al-Insān, translated by Fouad Serūjīi, $1^{\text {st }}$ edit., Amman, 2007

- 'Essam Zanātî, Ḥīmayat Ḥuqūq al-Insān fī İtār al-ūmam al-Mūtahidah, Cairo, 1998

- Gustave Le Bon, Hadārat al-'Arab, translated by Adel Zū'aiter, dar 'Essa Al-Babi al-Halabi, Cairo, 1969

- Hana’ Ibrāhīm \& ‘ Ali al-Ḥadībī, Ta' līm Ḥuqūq al-Insān, $1^{\text {st }}$ edit., Cairo, 2011

- Hanī Ta'īmāt, Ḥuqūq al-Insān wa Ḥūriyyātūh al-Assāssīyyah, $3^{\text {rd }}$ edit., Dar alShurūq, Amman, 2006

- Hassan ibn Farhan al-Malki, Hūrayyāt al-I'tiqād fĩ al-Qur'ān wa al-Sūnnah anNabawīyyah, Riyadh, 1430 A.H/ 2009A.D

- Hassānīn Bawādi, Ḥuqūq al-Insān bayn Matraqat al-Irhāb wa Sindān al-Gharb, Dar al-Fikr al-Jāmī' '̄', Alexandria, 2006

- Hassānīn Bawādi, Ḥuqūq al-Insān wa Damānāt al-Mūtaham qabl wa ba'd alMūhakamah, Alexandria, 2008

- Ibrāhīm Ma'amr, Dūr al-Mūnazamāt ad-Dawlīyyah al-Ghīr hūkūmīyyah fĩ Ḥīmāyat Ḥuqūq al-Insān, Ḥāla Taṭbīqiyya 'ala al-Mūnazāma al-‘Arabīyya lī Ḥuqūq al-Insān, M. A., Faculty of Law/al-Azhar Univ., 2011

- Jābir ar-Rāwī, Huqūq al-Insān wa Ḥūriyyātūh al-Assāssīyyah fĩ al-Qānūn alDawlī wā al-Shari'ā al-Islāmīyyah, $1^{\text {st }}$ edit., Amman, 1999

- Ja'far 'Abd el-Salām, "Huqūq al-Insan fì al-Islam" a research presented in a colloquium entitled "al-Islam fĩ Sharq Asia, Ḥadārah wa Mū'āsrah", Taipei, Taiwan, 1425 A.H/ 2003 A.D p. 1-36

- Jāsim Muhammad Rashid al-'Esawy, al-Wāthīqa an-Nabawīyyah wā al-Aḥkām al-Shar'īyya al-Mū stafadah minha, $1^{\text {st }}$ edit., Dar al-Sahābah, Sharjah:UAE, 1427 A.H/ 2006 A.D

- Jūbrān Massoūd, Ar-Ra'id (Mū 'jam Laghawy 'Așrī rutabat mū frādātū h wifqā lī hurufhā al-ūla), $3^{\text {rd }}$ edit., Dar al-'Elm lī al-Malāyīn, Beirut, 1978

- Karima al-Tāī \& Hūsseīn al-Darderī, Ḥuqūq al-Insān wa Ḥūriyyātūh alAssāssīyyah fì al-Mawathīq al-Dawliyyah wa ba'd al-Dasātīr al-'Arabīyya, $1^{\text {st }}$ edit., Amman, 2010

- Laura Veccia Vaglieri, Defa' 'An Al-Islam, translated by Mounir al-Baalabki, dar Al- 'Elm Li- Al malayyin, Beirut, 1960 
- Mahmūd Qandil, al-Ūmam al-Mūtahīdah wa himāyt Huqūq al-Insān, $1^{\text {st }}$ edit., Markaz al-Qahira lī derāsāt hūqūq al-Insān, Cairo, 2009

- Markaz derāsāt al-Wīhda al-'Arabiyya, Hūqūq al-Insān al-'Arabi, $1^{\text {st }}$ edit., Beirut, 1999

- Māzin Shandab, Dā'īsh (Māhīyatūh, Nashātūh, Irhābūh, Ahdāfūh, Istrātîjīyatūh), $1^{\text {st }}$ edit., (w.p.), 2014

- Muhammad al-Ghazālī, Ḥuqūq al-Insān bayn Ta'ālīm al-Islām wā I'lān al-Ūmam al-Mūtahidah, $4^{\text {th }}$ edit. Dar Nahdat Mișr, Cairo, 2005

- Muhammad 'Elwān, Muhammad al-Mūsā, al-Qānūn Al-Dawli lī Ḥuqūq al-Insān.. al-Māṣādīr wa wāsaīl al-Rīqābah, $1^{\text {st }}$ edit., Dar al-thaqāfah lī al-Nashr wa al-tawzī', Amman, 2005

- Muhammad Hamīd Allāh, Majmū'at al-wathā'q al-Siyāsīyah fī al-'Ahd alNabāwy wa al-Khīlāfah al-Rāshidah, $6^{\text {th }}$ edit., Dar an-Nafāiīth, Beirut, 1987

- Muhammad Muhammad, al-Hūqūq al-Siyāsīyah li al-Aqalīyyāt fī al-Fiqh AlIslāmī wa al-Nūzūm al-Dūstūriyya al-Mū'āsirah, Dar al-Nahd̄a al- 'Arabiyya, Cairo, 2007

- Muhammad Sa'īd Ramadan Al-Būty, Fiqh as-Sirah, maktabet al-Sharq al-Jadid, Baghdad, 1990

- Muhammad Taqî-ud-Dîn al-Hilālî\& Muhammad Mohsin khān, Translation of the Meanings of the Noble Qur'ān in the English Language, king Fahd complex for the printing of the Holy Qur'ān, Madinah, K.S.A, 2017 http://www.publicationsimg.qurancomplex.gov.sa - 15/8/2017.

- Nasir al-Sayed, al-Hiimāyah al-Dawliyya lī-hūrayat I'tīnāq al-Dīyānah wa Mūmārasat Sha'āirha, Alexandria, 2012

- Nesrīn Muhammad 'Abdū Hassūna, Ḥuqūq al-Insān al-Mafhūm wa al-Khașāịṣ wa al-Tașnīf wa al-Mașādir, (w.p.), 1436A.H/ 2015 A.D

- Qaḍrī 'Abd al-Majīd, Al-I'lām wā Ḥuqūq al-Insān- Qadāāya fikrīyyah, Alexandria, 2008

- Qaḍrī al-Atrash, Madkhl ela Qadaya Ḥuqūq al-Insān, Libya, 2008

- Rad̄wān Zīyāda, Masīrat Ḥuqūq al-Insān fī al- 'Ālam al-’Arabi, $1^{\text {st }}$ edit., alMarkaz al-Thaqāfī al-'Arabi, Beirut,, 2000

- Sa'dī Al-Khațīb, Huqūq al-Insān wā Damānatahah al-Dīstūrīyya fī ethnā wā 'ūshrūn dawla 'Arabiyya: Dirāsa Mūqāranah, 1 st edit., Bierut, 2007

- Sāmir Abū Rūmān, Dā'īsh: Tanzīm al-Dawla fì 'Ūoon al-Shū'ūb, Markaz alBayān lī al-Būhūuth wā al-Dirāsāt, (w.p.), 2015

- Șūfĩ Ḥassan Abū Țāleb, Tārikh an-Nuzum al-Qanūniyyah wā al-Ijtimā'iyyah, Dar al-Nahḍa al-'Arabiyyah, Cairo,1976 
- Sūhail al-Fatlāwī, Ḥuqūq al-Insān, $1^{\text {st }}$ edit., Amman, 2007

- Taïeb Baccouche,"Athr Huqūq al-Insān fī Tațīr al-mafāhīm al-Thaqāfĩyyah", alMajala Al-'Arabiyya lī- Ḥuqūq al-Insān, $3^{\text {rd }}$ year- Vol. 3, al-Ma'had al-'Arabi $\overline{1}^{-}$ Ḥuqūq al-Insān, Tunisia, Sep. 1996, p. 97-110

- Tārīq Rakhā, Qānūn Ḥuqūq al-Insān bain al-Naẓarīyyah wā al-Taṭ̂īq fī al-Fikr al-Waḍ' '̄i wā al-Sharī'à al- Islāmīyya, Cairo, 2005

- Ūmar Al-Hadīthī, Tajrīm al-Ta'āsūf fĩ Ist'māl al-Haq bī Wașfahū Sabab mn Asbāb al-Ibāḥa, $1^{\text {st }}$ edit., Dar al-Thaqāaa, Amman, 2011

- Ūmar Farhāty, Āliyāt al-Himāya al-Dawlīyya lī-Huqūq Al-Insān wā huryātūh alĀsāsīyya, $1^{\text {st }}$ edit., Dar Al-Thaqāfa lī al-Nashr wā al-Tawzī', Amman, 2012

- 'Ūrūpa al-Khazrajīi, al-Qānūn al-Dawlī lī Ḥuqūq al-Insān, $2^{\text {nd }}$ edit., Amman, 2012

- Yūsūf 'Awād and Others, Ḥuqūq al-Insān fī al-Hayāh at-Tarbāwīyya: al-Waqia' wā at-Tațalū'āt, $1^{\text {st }}$ edit., Dar al-Manāhīj lī al-Nashr wā al-Tawzīa', Amman, 2008

\section{Foreign sources}

- Bernard O'kane, Mohamed Abbas \& Iman Abdul Fattah, The illustrated Guide to the Museum of Islamic Art in Cairo, The American University in Cairo press, Cairo, 2012

- Cecilia M. Bailliet, "Reinterpreting Human Rights through global Media": A case study of Al-Jazeera English, Canadian Journal of "Human Rights", 2013, p. 38-77

- Cole Bunzel, from paper state to caliphate:(the ideology of the Islamic state), the Brookings project on U.S Relations with the Islamic world, analysis paper, no. 15, March 2015

- Esin Atil, Art of the Arab world, Washington, D.C., 1975

- Eva Baer, Metalwork in Medieval Islamic Art, New York, 1983

- Hartwig Hirschfeld, "The Arabic Portion of the Cairo Genizah at Cambridge", the Jewish Quarterly Review, vol. 15, no. 2, University of Pennsylvania press, Jan. 1903, p. 167-181, http:// www.jstor.org/stable/14500432- 09-08-2016

- Howard C. Hollis, "An Arabic censer", Bulletin of the Cleveland museum of Art, Vol. 25, No. 7, July.1938,137-138 http://www.jstor.org/stable/25137948 -22-22018

- Lucie Pruvost, Déclaration universelle des droits de l'homme dans l'Islam et Charte internationale des droits de l'homme, Islamochristiana, issue no.9, 1983, p. 141-159, https://www.acihl.org/articles.htm?article_id=5 - 25/2/2018

- Muhammad Amin Al-Midani, Les Droits de l'Homme et l'Islam. Textes des organisations arabes et Islamiques. 2ème edition, publié par l'Association OrientOccident et le Centre Arabe pour l'Education au Droit International Humanitaire et aux Droits Humains, Université de Strasbourg, 2010 https://acihl.org/publications.htm?article id=25 - 2/3/2018 
- Ranee A. Katzenstein \& Glenn D. Lowry, "Christian Themes in ThirteenthCentury Islamic Metalwork”, Muqarnas, Vol.1, 1983, p.53-68

- Tasha Voederstrasse\& Tanya Treptow, A cosmopolitan City Muslims, Christians, and Jews in Old Cairo, the Oriental Institute of the University of Chicago, 2015

- The king James Version of The Holy Bible, original publish date: March 2001, revised: January 2004, http://www.bookbindery.ca/KJBIBLE.pdf- 16-2-2018

- The universal Jewish Encyclopedia, Vol. 10, New York, 1969

- Todd Landman, "Measuring Human Rights: principle, Practice and policy", "Human Rights" Quarterly, Vol. 26, No. 4, November 2004, p. 906-931

- Turkish Covenant, Roll no. 4, dimensions 40x70 C.M, Library of Supreme Council of culture, Cairo.

\section{Websites}

- http://academic.eb.com/levels/collegiate/article/Ibn-Taymiyyah/41931-24-8-2017

- http://academic.eb.com/levels/collegiate/article/monasticism/109510\#38692.toc24-8-2017

- https://www.si.edu/exhibitions/engaging-the-senses-arts-of-the-islamic-world$\underline{6231-2-3-2018}$

- https://www.si.edu/object/fsg_F1955.10-3-3-2018

- https://www.loc.gov/catdir/cpso/romanization/arabic.pdf -2-8-2016 


\section{Plates}

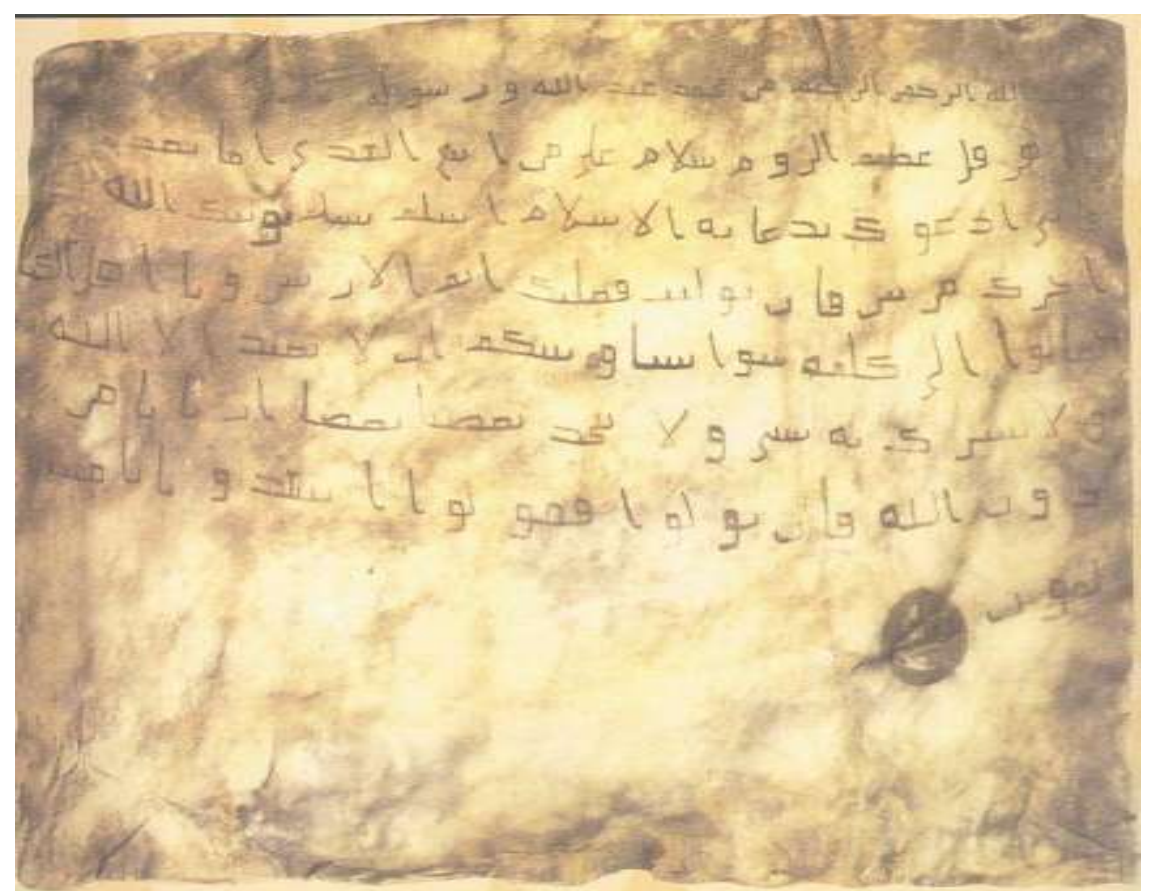

\section{(pl. 1)}

Prophet Muhammad's message to Heracles (the mighty of the Romans) http://www.al2la.com/vb/t56164.html accessed in 15/9/ 2017 at 19:02 UTC

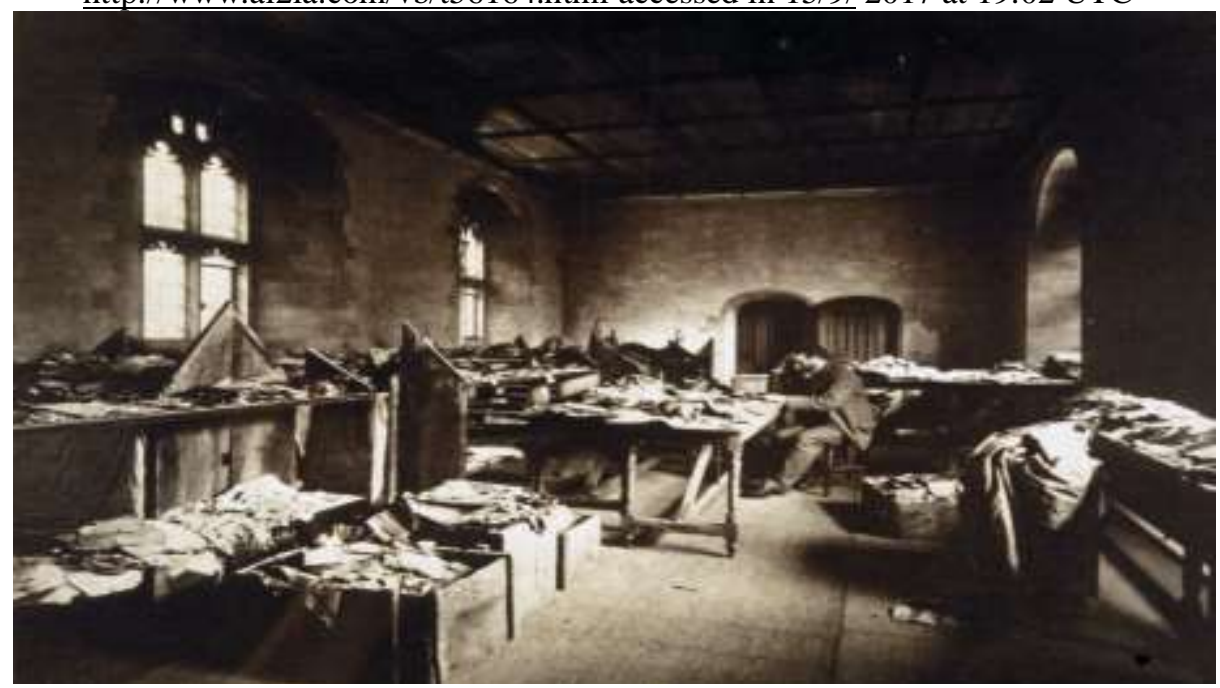

(pl. 2)

Cairo Genizah,

Tasha Voederstrasse, Tanya Treptow, A cosmopolitan City, Fig. 2.1, p. 27 


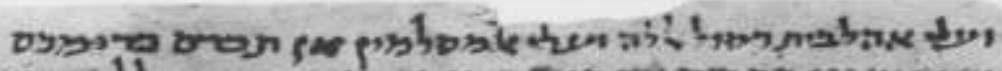

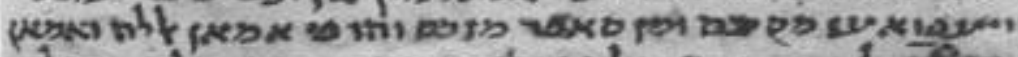

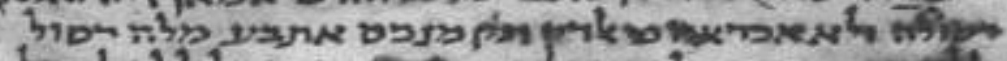

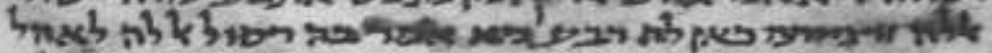

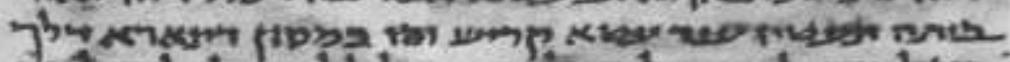

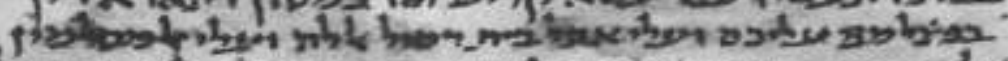

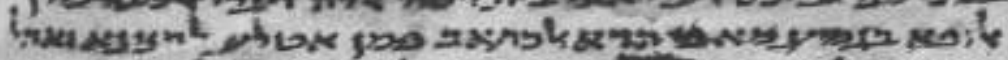
-

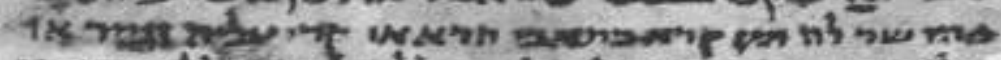

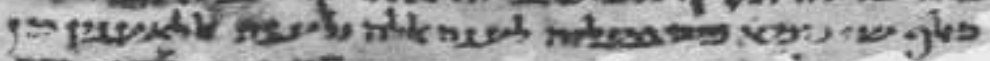

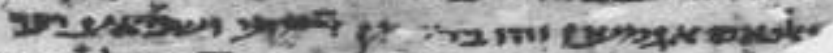

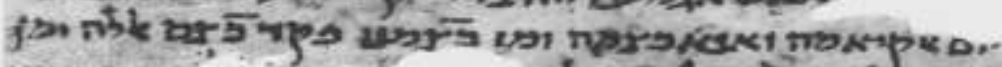

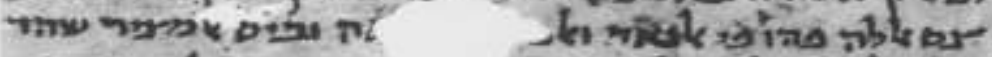

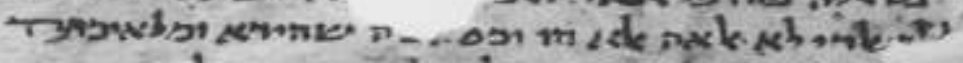

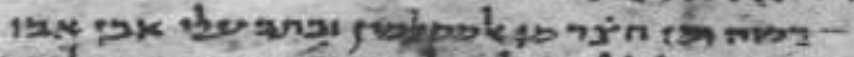

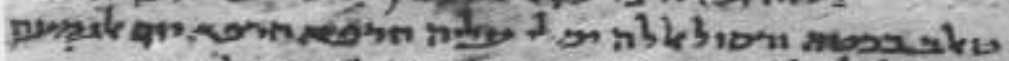

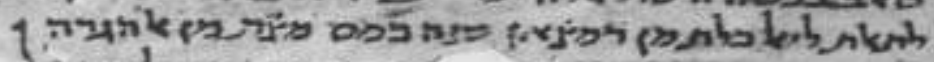
1

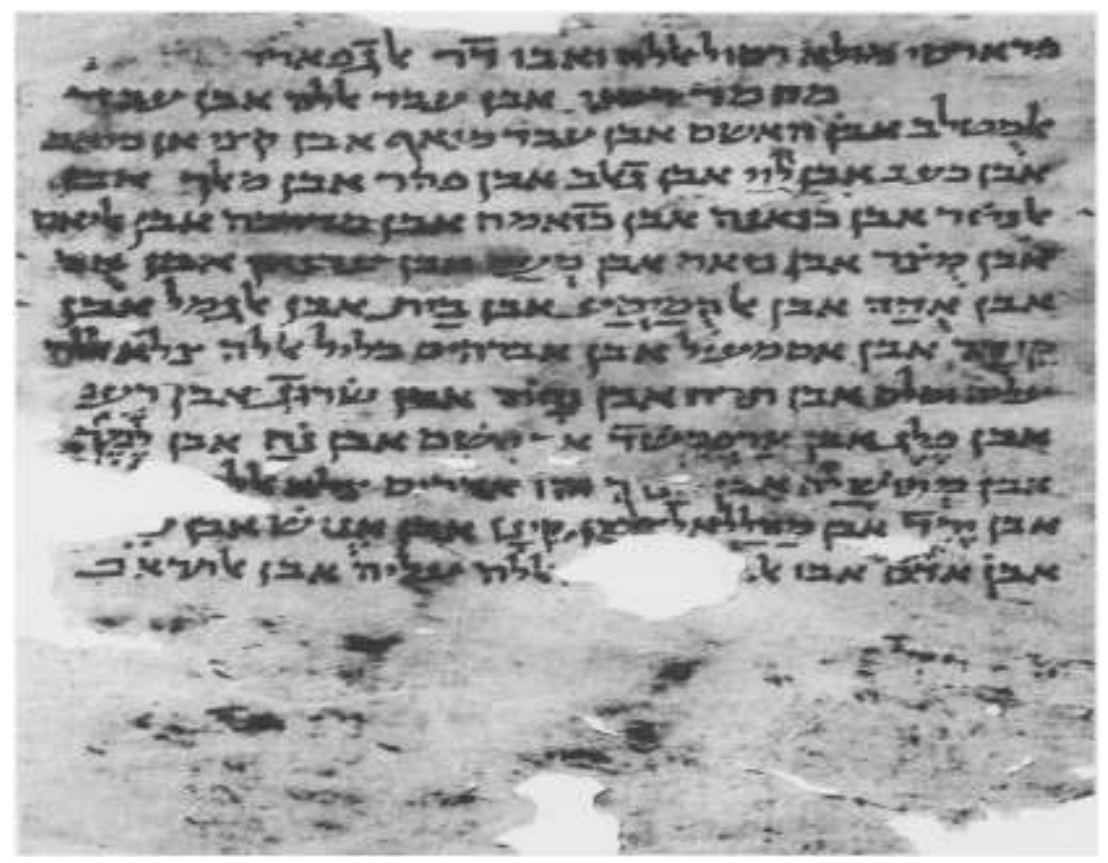

(pl.3)

Prophet Muhammad's message to people of Maqna in Arabic written in Hebrew letters

Hartwig Hirschfeld, the jewish Quarterly Review, vol. 15, no. 2, fol. 2recto\& verso,p. 178,

(http:// www.jstor.org/stable/14500432, accessed 09-08-2016 00:42 
(pl.4)

A Turkish copy of Prophet Muhammad's covenant to Christians Library of supreme council of culture, Cairo, Roll no. 4, dimensions 40x70 C.M http://www.kwikne ws.my/news/letterto-all-christians-

from-prophet$\underline{\text { muhammad-saw }}$

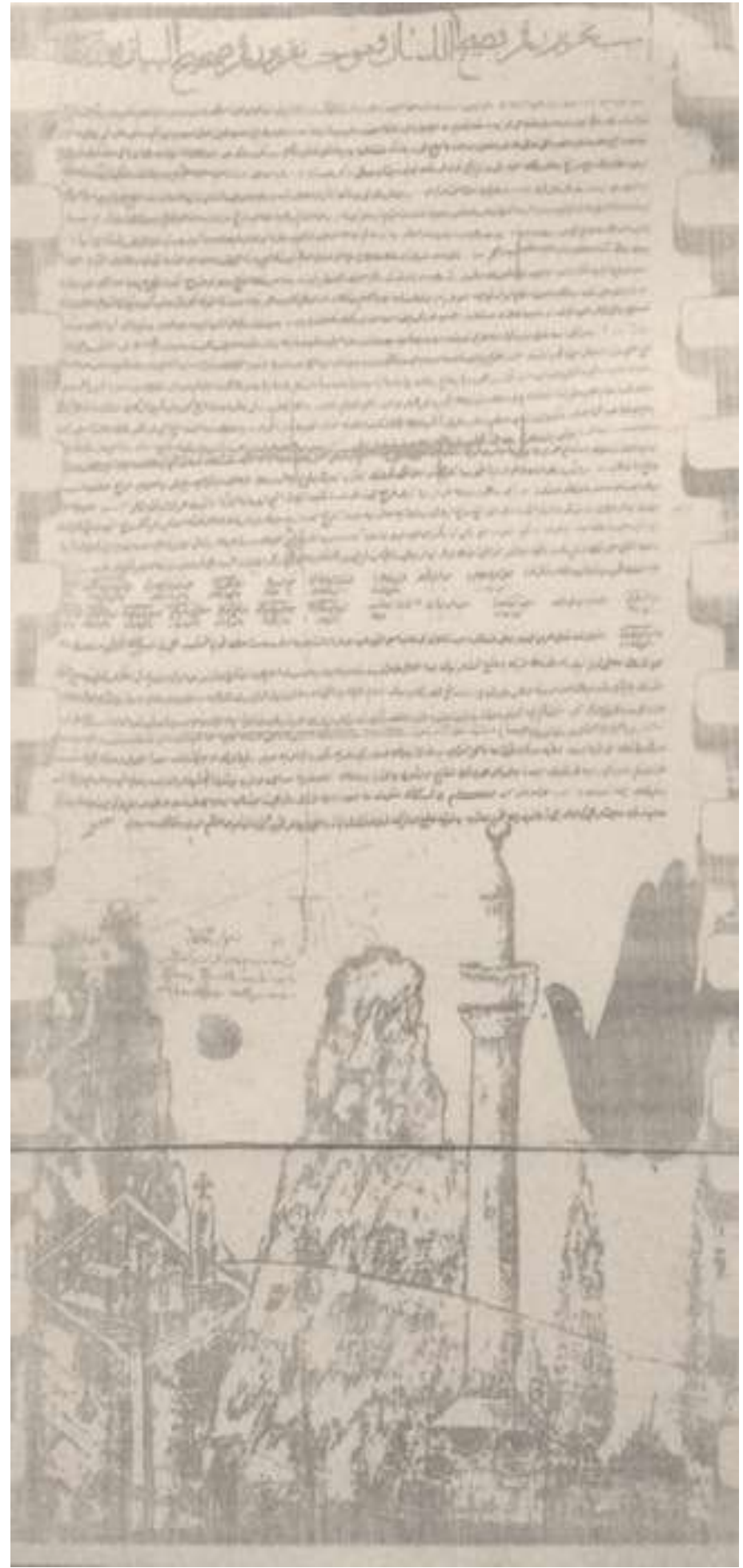




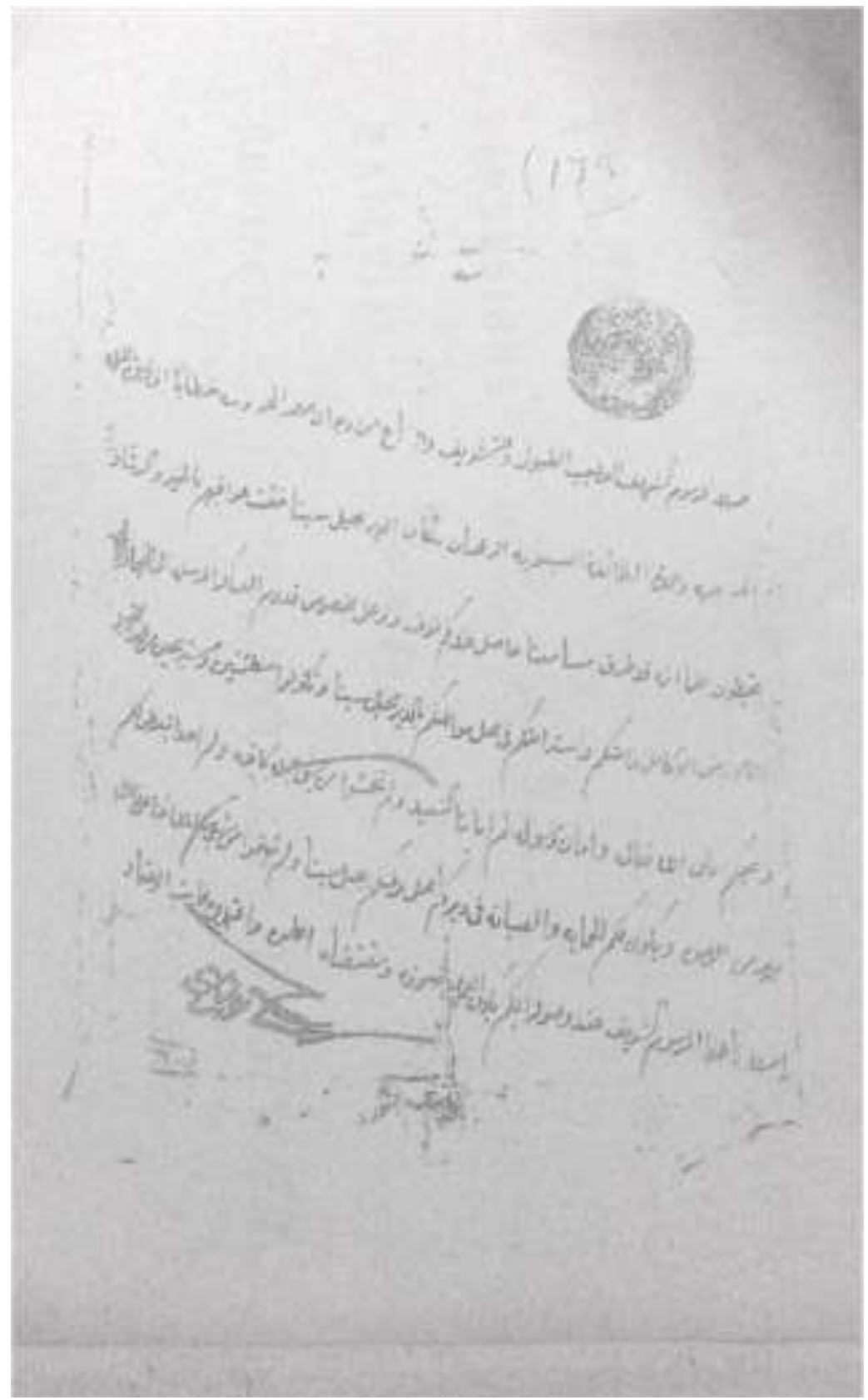

\section{(pl. 5)}

An arabic firman signatures by Divan Misr al-Mahrusa with Muhammad Ali Pasha seal

Library of supreme council of culture, Cairo, Roll no. 175, dimensions $32.5 \times 21$ C.M, 
(PI. 6)A wooden door riveted with silver signed by the craftsman "Yahū da Aslān" The museum of Islamic Art in Cairo, $13^{\text {th }}$ century A.H $/ 19^{\text {th }}$ century A.D. Record no. 3737 captured by Abo El-'Ela Khalil
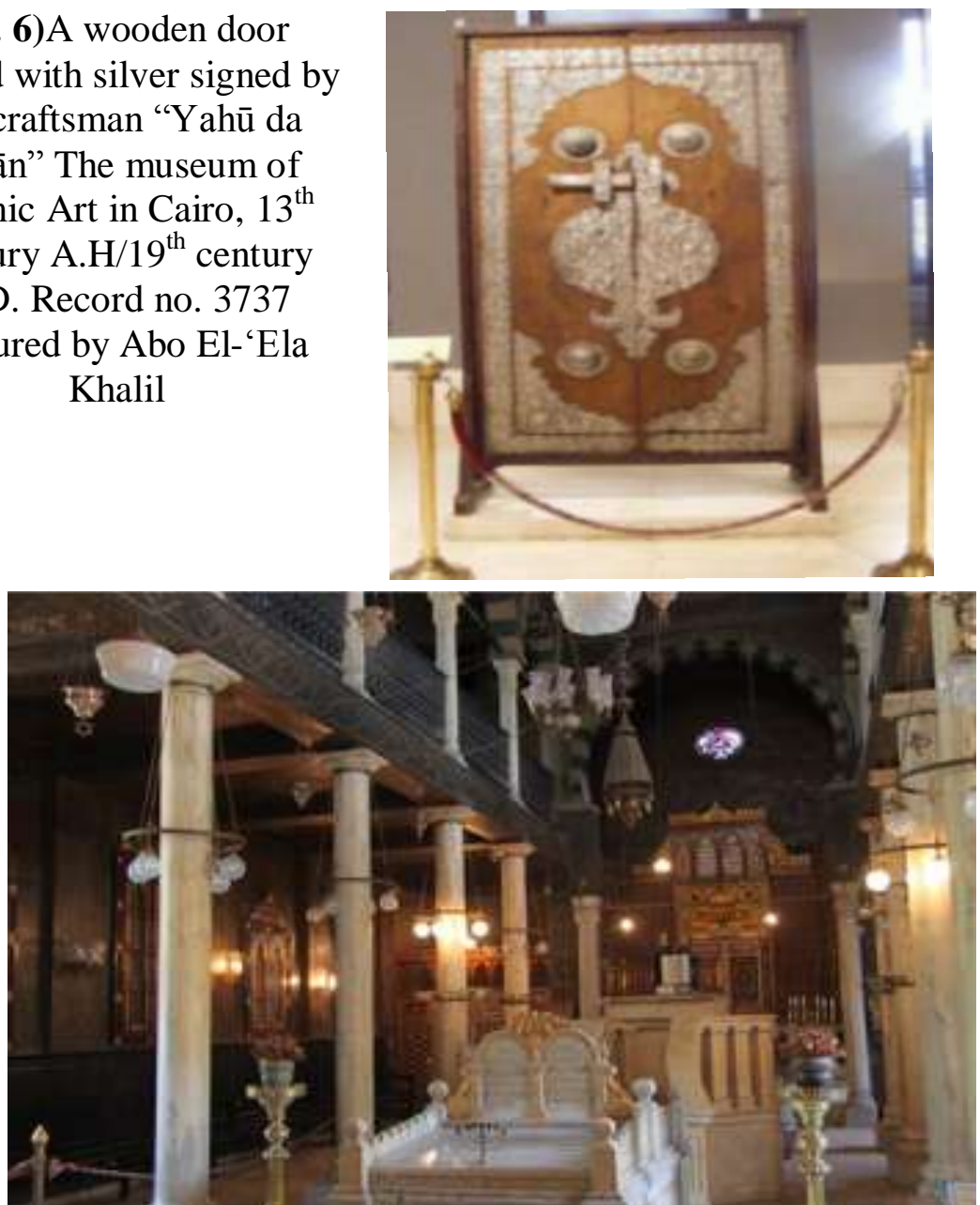

(pl. 7)Ben Ezra Synagogue from interior

https://www.google.com.eg/search, accessed in 21/8/2017 at 12:54 UTC

(PI. 8)A copper chandeliers hanged down to the right of the Alter bearing names of the four orthodox Caliphs Ben 'Ezra synagogue, Mugama' al-adian" in Old Cairo captured by the Archaeological Abo El-'Ela Khalil

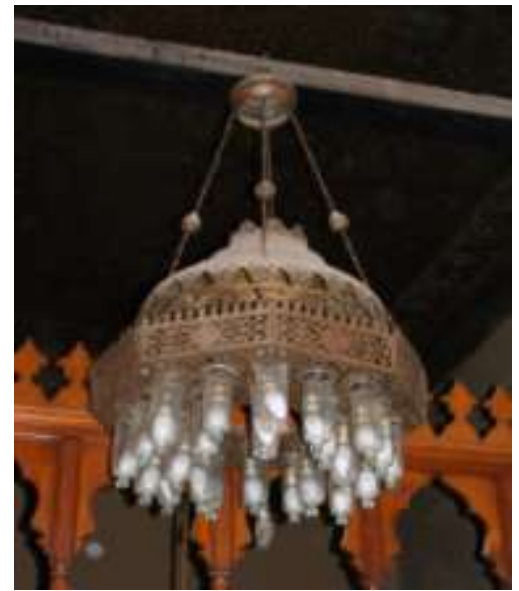


(PI. 9)A conical shaped copper

chandelier, bearing the name of Sultan Al-

Manșoūr Qalawoūn Ben

'Ezra synagogue, Mū jama' al-Adiān” in Old

Cairo captured by the Archaeological Abo El-'Ela Khalil
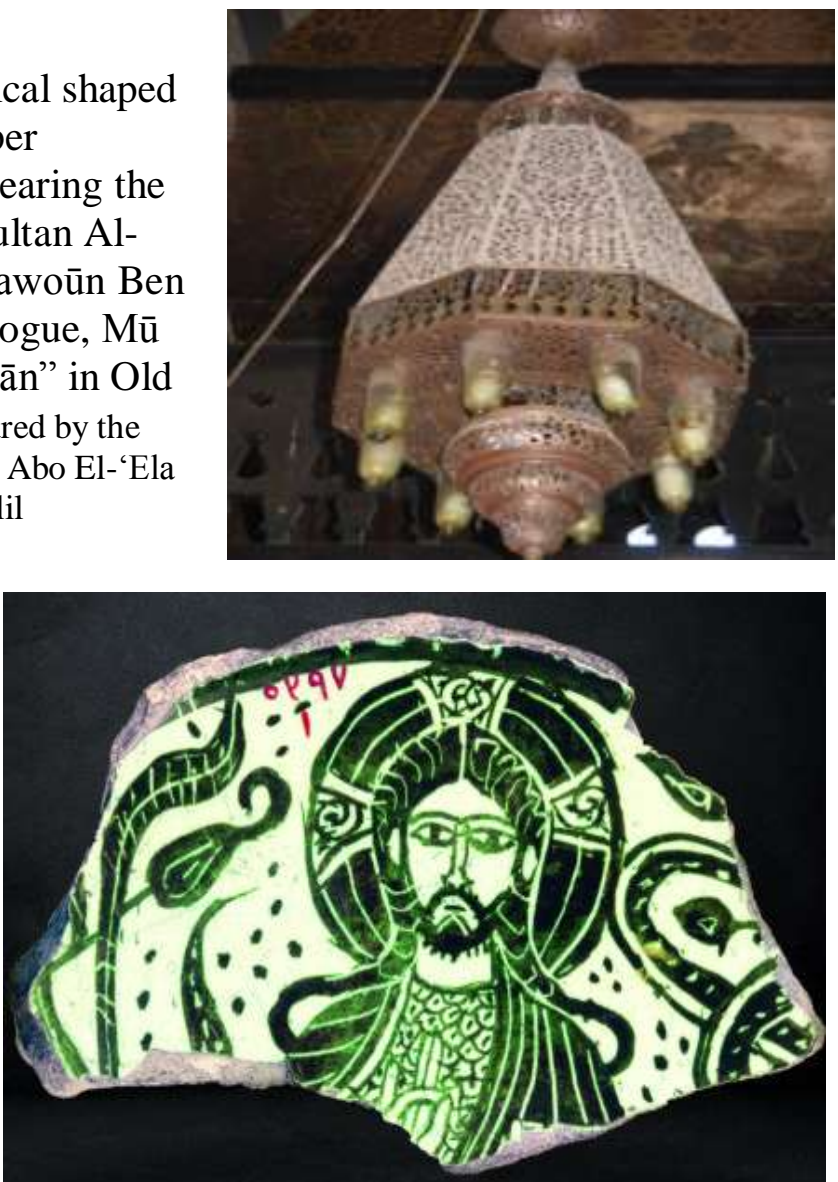

(PI. 10)Monochrome lustre-painted bowl fragment inv. No. 5397/1, Cairo, museum of Islamic art, Fustat. Fatimid epoch $\left(5^{\text {th }}-6^{\text {th }}\right.$ century A.H/ $11^{\text {th }}-12^{\text {th }}$ century A. D). Bernard O'kane, Mohamed Abbas \& Iman Abdul Fattah, The Illustrated Guide to the Museum of Islamic Art in Cairo, p. 59

(PI. 11)Ceramic underglazed painted fragment,

No. 13174, Cairo, museum of Islamic art, Egypt or Syria, $7^{\text {th }}$ century A.H/ $13^{\text {th }}$ century A.D. Bernard O'kane, The Illustrated Guide to the Museum of Islamic Art in Cairo, p. 112

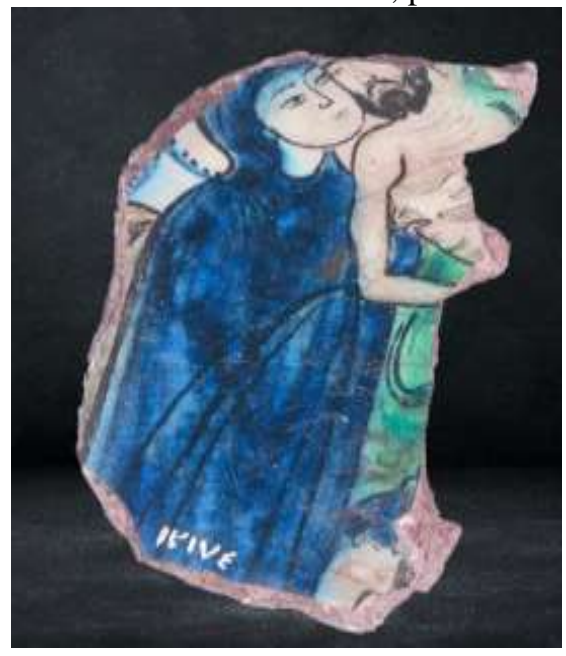




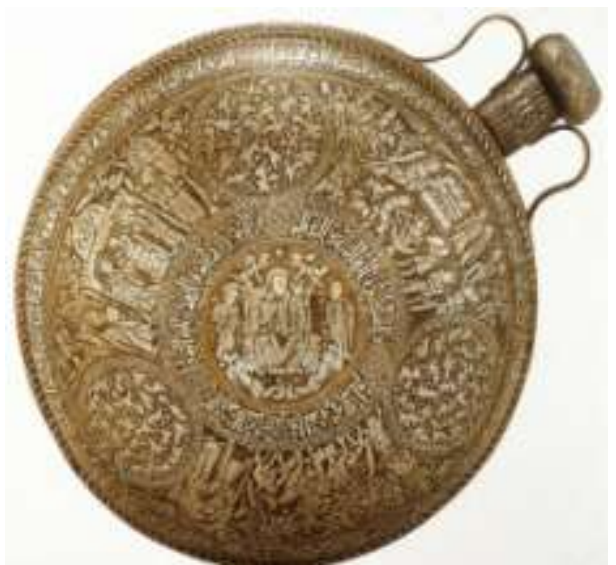

(Pl. 12)A canteen of brass inlaid in silver no. F1941.10, Freer Gallery of Arts, Washington Syria, mid of the $7^{\text {th }}$ century A.H/ $13^{\text {th }}$ century A.D. https://www.si.edu/exhibitions/engaging-the-senses-arts-of-the-islamic-world-6231

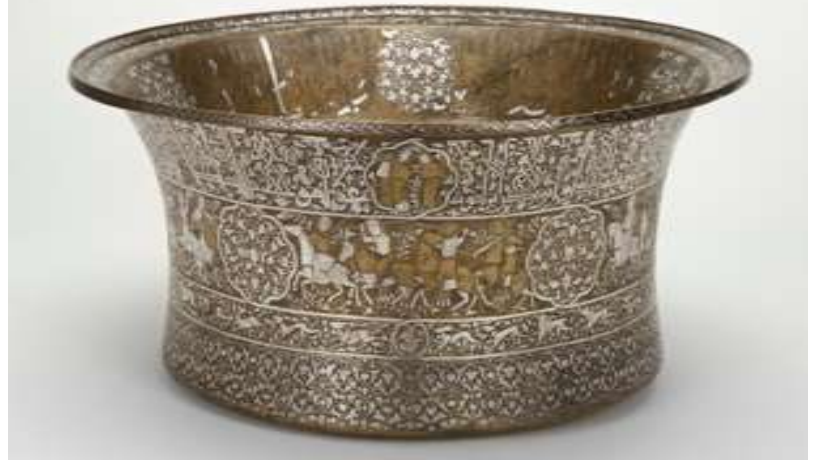

(Pl. 13)

A brass basin inlaid with silver, no. F1955.10, Freer Gallery of Arts, Washington Syria, dated back to 659-669 A.H/1239-49 A.D. https://www.si.edu/object/fsg_F1955.10

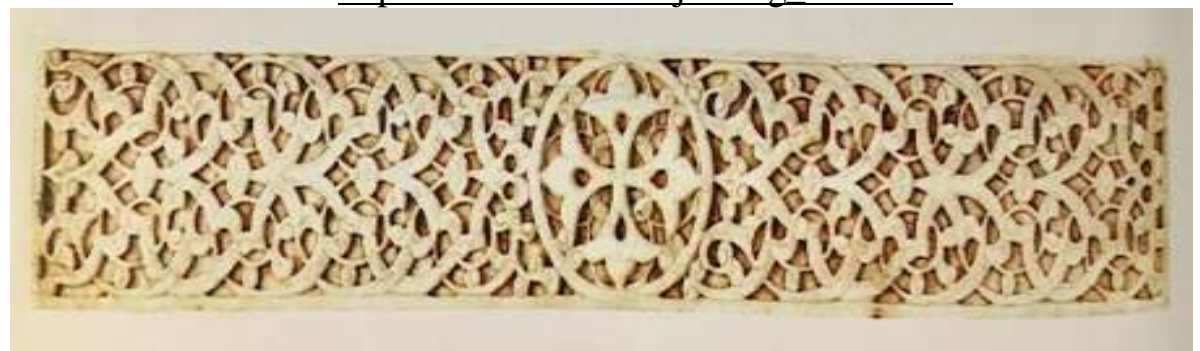

(PI. 14)

A plaque of ivory, inv. No. 5620, Cairo, museum of Islamic art, Mamluk epoch $8^{\text {th }}$ century A.H/14 $4^{\text {th }}$ century A.D.

Bernard O'kane, The Illustrated guide to the museum of Islamic Art in Cairo, p. 332 
حرية العقيدة كما يكفلها الإسلام- في ضوء المخطوطات والوثائق الأثرية (در اسة تاريخية أثرية)

\section{د.بوسي تحمد حسين زيدان}

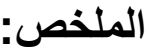

في الآونة الأخيرة، ارتكب المتطرفين الذين يسمون أنفسهم "داعش" اعمال

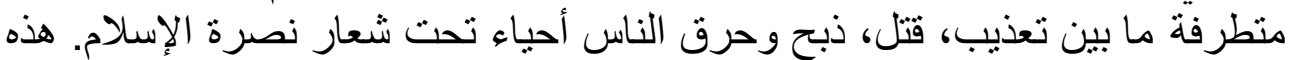

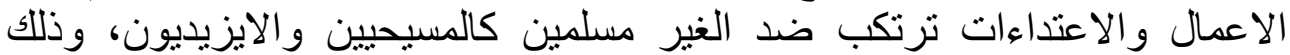

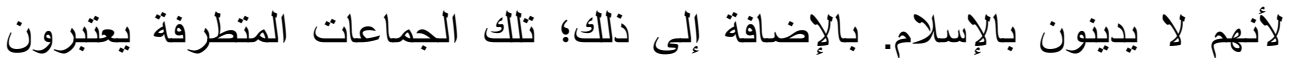

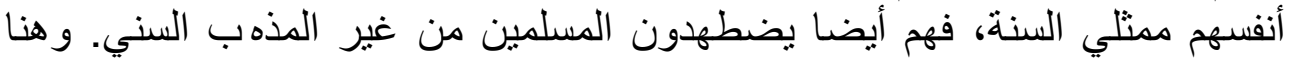

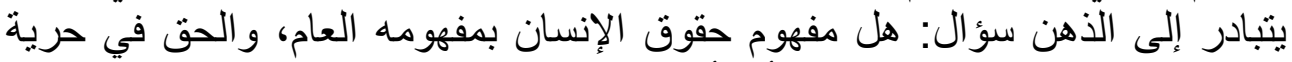

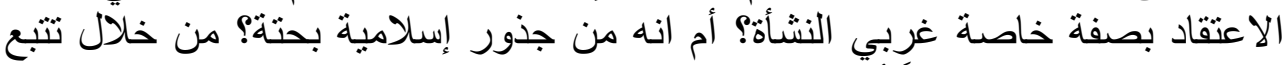

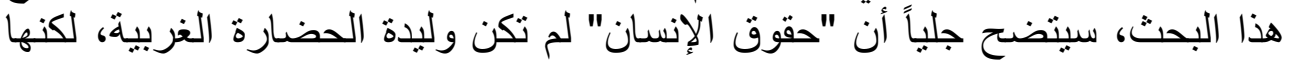

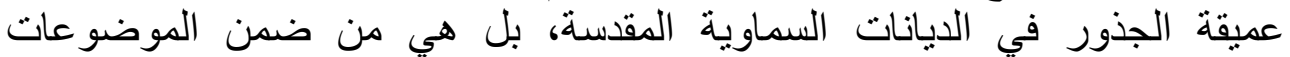

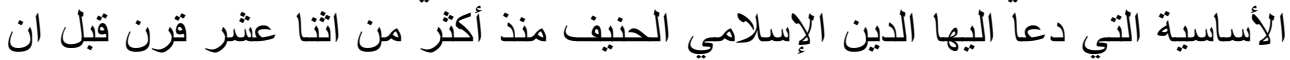

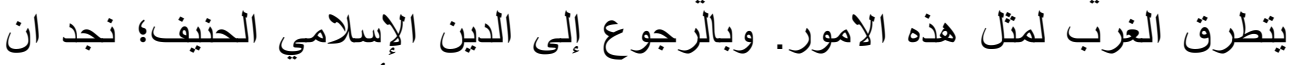

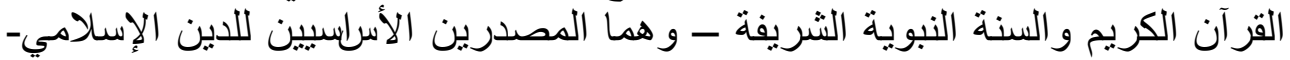

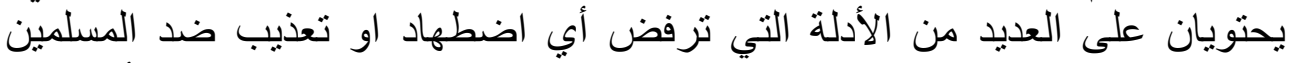

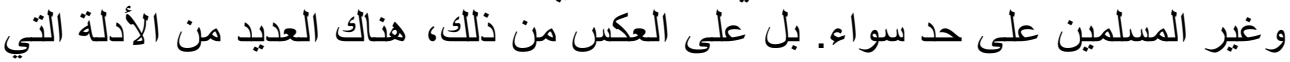

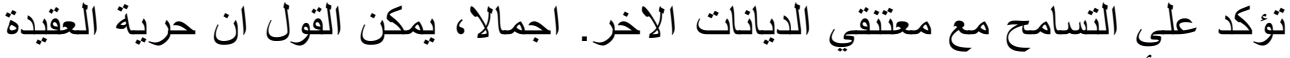

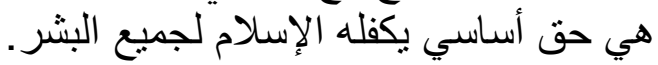

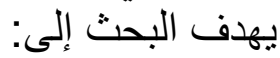
- التأكيد على أن الإسلام يعكس أصل حقوق الإنسان، وبالأخص حرية الاعتقاد.

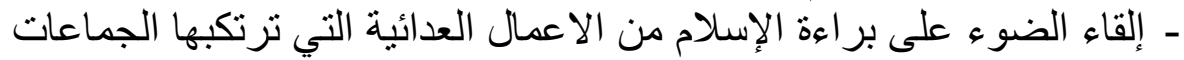
الدينية المتطرفة. - محاولة نشر مفاهيم الإسلام الصنه الصحيح.

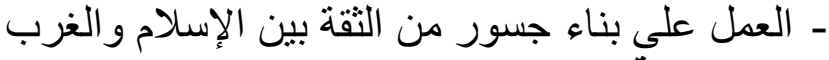

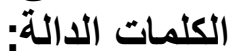
متطرفين، حقوق الانسان، حرية الاعتقاد، داعش، الدين الإسلامي، الأحاديث النبوية.

•أستاذ التاريخ والآثار الإسلامية المساعد- كلية السياحة والفنادق- جامعة قناة السويس dr.boussyzidan@tourism.suez.edu.eg 